\title{
antibiotics
}

ISSN 2079-6382

www.mdpi.com/journal/antibiotics

Review

\section{Antimicrobial Resistance and Reduced Susceptibility in Clostridium difficile: Potential Consequences for Induction, Treatment, and Recurrence of $\boldsymbol{C}$. difficile Infection}

\section{Simon D. Baines ${ }^{1, *}$ and Mark H. Wilcox ${ }^{2,3}$}

1 Department of Biological and Environmental Sciences, School of Life and Medical Sciences, University of Hertfordshire, Hatfield AL10 9AB, UK

2 Leeds Institute of Biomedical and Clinical Sciences, Faculty of Medicine and Health, University of Leeds, Leeds LS2 9JT, UK; E-Mail: mark.wilcox@nhs.net

3 Department of Microbiology, Leeds Teaching Hospitals NHS Trust, The General Infirmary, Leeds LS1 3EX, UK

* Author to whom correspondence should be addressed; E-Mail: s.baines2@herts.ac.uk; Tel.: +44-1706-284-549.

Academic Editor: Yung-Fu Chang

Received: 31 May 2015 / Accepted: 3 July 2015 / Published: 10 July 2015

\begin{abstract}
Clostridium difficile infection (CDI) remains a substantial burden on healthcare systems and is likely to remain so given our reliance on antimicrobial therapies to treat bacterial infections, especially in an aging population in whom multiple co-morbidities are common. Antimicrobial agents are a key component in the aetiology of CDI, both in the establishment of the infection and also in its treatment. The purpose of this review is to summarise the role of antimicrobial agents in primary and recurrent CDI; assessing why certain antimicrobial classes may predispose to the induction of CDI according to a balance between antimicrobial activity against the gut microflora and $C$. difficile. Considering these aspects of CDI is important in both the prevention of the infection and in the development of new antimicrobial treatments.
\end{abstract}

Keywords: Clostridium difficile; antimicrobial agents; resistance; reduced susceptibility; recurrence 


\section{Introduction}

Clostridium difficile infection (CDI) remains a substantial worldwide burden on healthcare systems, despite significant research and investment over the past four decades. CDI normally, but not exclusively, emerges following one or more course(s) of antimicrobial therapy for an unrelated condition, which perturbs microbial colonisation resistance within the host. Other risk factors that have been linked to the development of CDI include proton pump inhibitors and the use of anticancer agents. Antimicrobial therapy facilitates germination of $C$. difficile spores within the colon and production of toxin A and/or toxin B. C. difficile is the aetiological agent of pseudomembranous colitis (PMC) and is implicated in approximately $30 \%$ of cases of antibiotic-associated diarrhoea [1,2]. Most antimicrobial agents have been implicated in the induction of CDI, but clindamycin, third-generation cephalosporins, fluoroquinolones, and aminopenicillins are particularly noted for their propensity to induce CDI [3]. Despite improved clinical management strategies for CDI, healthcare costs for treating CDI remain high and were estimated at \$1.1-3.2 billion in the USA [4,5]. CDI is a complex and multifactorial disease, involving the host immune response to $C$. difficile and its toxins, antimicrobial agents, their effect of the indigenous gut microflora and $C$. difficile, and the virulence of the infecting C. difficile strain (Figure 1). Antimicrobial agents are an intrinsic aspect of CDI; in both its induction and treatment. The widespread emergence of hypervirulent PCR ribotype (RT) 027 highlighted the potential importance of antimicrobial (fluoroquinolone) resistance in facilitating the epidemic spread of $C$. difficile clones [6].

This review will concentrate on antimicrobial susceptibility and resistance in $C$. difficile to the antimicrobial agents that induce and treat CDI, considering the prevalent ribotypes currently in circulation, mechanisms for reduced susceptibility and resistance, and pharmacokinetics of the antimicrobial agents. Furthermore, a prediction of antimicrobial agent washout will be estimated using mass-balance theory for a range of antimicrobials, to suggest how the timing of CDI (primary or recurrent) may be influenced by antimicrobial susceptibility. We will also explore how the susceptibility of important indigenous gut microflora groups may influence the risk of CDI. 


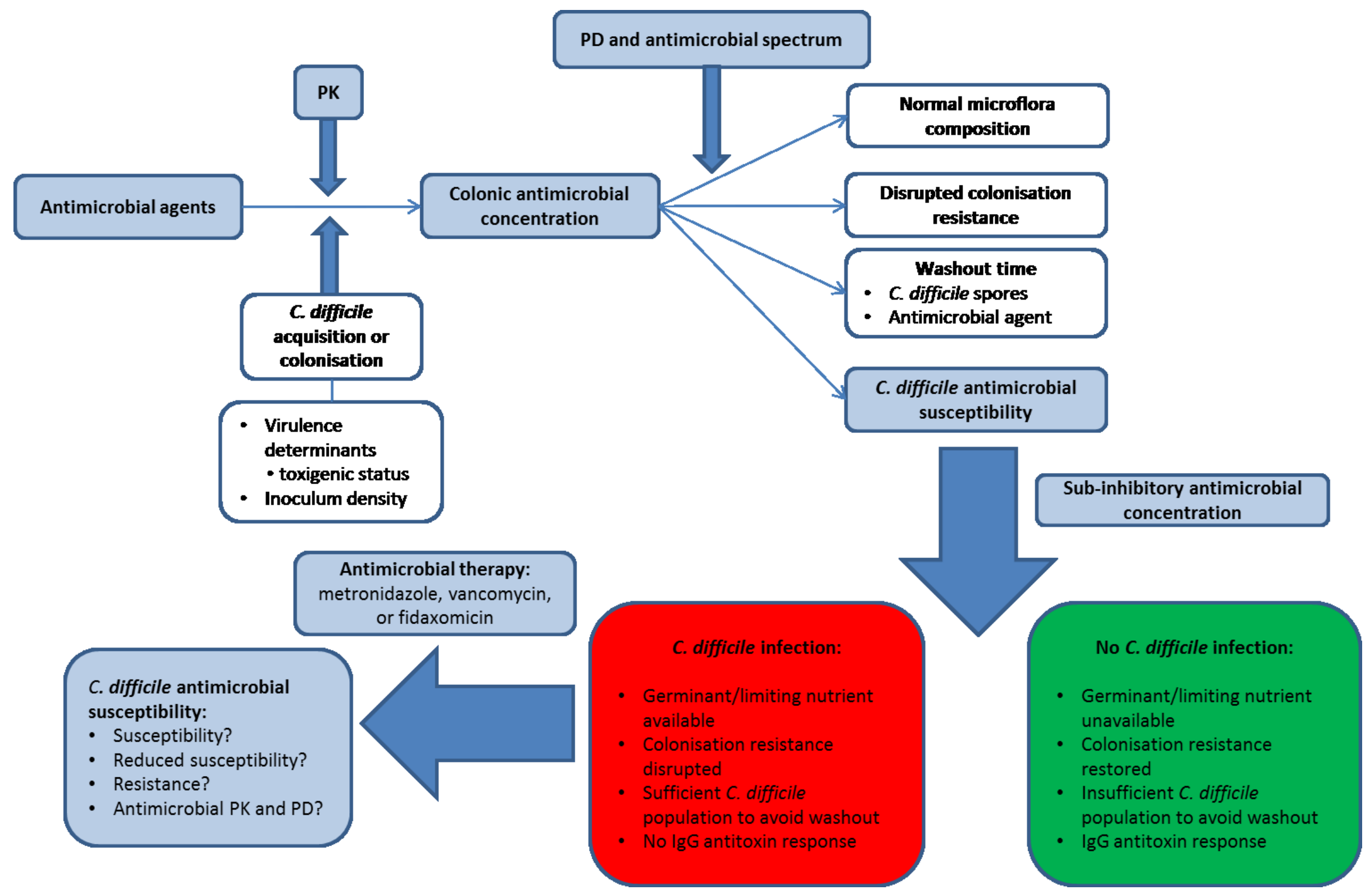


Figure 1. Factors involved in the development of Clostridium difficile infection (CDI). Blue shaded boxes involve antimicrobial agents. PK, pharmacokinetics; PD, pharmacodynamics. Antimicrobial agents differ in their pharmacokinetics (PK) and therefore in the luminal concentration that is present (and bioactive) in the human colon. In order for CDI to develop, a patient must either acquire toxigenic $C$. difficile from an exogenous source or be colonised with an endogenous strain. The antimicrobial agent disrupts the indigenous microflora to an extent governed by its antimicrobial spectrum of activity and pharmacodynamic (PD) profile, and a steady state concentration of antimicrobial agent may be reached by the end of dosing. The antimicrobial agent (and C. difficile spores) may then be washed out of the colon to a sub-inhibitory concentration, the speed of which depends on the steady-state drug concentration in the colonic lumen and the colonic transit time of the patient. The observation and timing of CDI depends on host immunological factors, $C$. difficile-specific factors (antimicrobial susceptibility to the inciting agent and the inoculum density of spores), and the rate and extent of recovery in the indigenous gut microflora. $C$. difficile spores do not outgrow in the presence of supra-inhibitory concentrations of antimicrobial agents, but once concentrations are sub-inhibitory then CDI may develop assuming the nutritional environment is conducive for spore germination and outgrowth (this may indicate prolonged disruption of colonisation resistance) and also that there is no IgG antitoxin response in the patient. Antimicrobial therapy for CDI may then be initiated by clinicians, the initial success of which depends on the PK/PD profile of the therapeutic agent and the susceptibility of the $C$. difficile strain. Whether recurrent CDI is subsequently observed may then depend on the degree to which the CDI therapy has negatively impacted on the indigenous gut microflora, the concentration of $C$. difficile spores remaining in the colon of the patient, whether the antimicrobial agent may persist in the colon or potentially adhere to $C$. difficile spores, and whether an $\operatorname{IgG}$ antitoxin response is observed. 


\section{Ribosomally Active Antimicrobial Agents}

\subsection{Clindamycin}

Clindamycin was the first antimicrobial agent linked to pseudomembranous colitis in the mid-1970s by Tedesco and colleagues in a prospective study of 200 patients [7]. The authors reported $21 \%$ incidence of diarrhoea and 10\% incidence of pseudomembranous colitis (PMC) following exposure to clindamycin. The authors noted that risk of PMC was 3-4 times greater following oral rather than parenteral clindamycin. Subsequently (in the late 1970s), the aetiology of CDI was determined when both $C$. difficile and its cytotoxic activity were demonstrated in faeces from PMC patients [1,2]. Clindamycin use has declined since clinical observations that this agent was a potent antimicrobial for inducing CDI. Surveillance for clindamycin resistance in $C$. difficile has identified multiple possible resistance mechanisms. Indeed, before highly discriminatory molecular typing methods were available, resistance to clindamycin was one characteristic that suggested that $C$. difficile subtypes existed within the same endemic ribotype (RT) 001 strains [8]. Antimicrobial susceptibility in $C$. difficile to clindamycin varies substantially between RTs and also according to geographical location. Freeman and colleagues recently published the results of a prospective susceptibility testing trial (ClosER) which encompassed 22 European countries and 953 C. difficile isolates [9]. Wide variations in RT prevalence were observed between countries and clindamycin resistance (MIC $\geq 8 \mathrm{mg} / \mathrm{L}$ ) was present in $49.6 \%$ of isolates in multiple (including prevalent) RTs; intermediate resistance (MIC $4 \mathrm{mg} / \mathrm{L}$ ) and susceptibility $(\leq 2 \mathrm{mg} / \mathrm{L})$ were observed in $12.7 \%$ and $37.6 \%$ of isolates, respectively, with a MIC range of 0.125 to $>64 \mathrm{mg} / \mathrm{L}$ [9]. Clindamycin-resistant $C$. difficile have also been observed in other studies in Europe, Asia, North America (including RTs 017, 018, 001), and the Middle East [10-23]. Indeed, outbreaks of CDI attributed to clindamycin resistant $C$. difficile have been reported for RT027 [24,25] and other genetic types [26], with clindamycin exposure documented as a specific risk factor in CDI outbreaks. $\mathrm{RT}$ is not necessarily a predictor of resistance, perhaps with the exception of fluoroquinolone resistance in epidemic clones of RT027, given that the majority of susceptibility studies demonstrate susceptible and resistant strains that share the same RT.

A true understanding of MICs is governed by the susceptibility testing method employed. For simplicity, many testing studies use antimicrobial-gradient based methods such as the E-test (Biomerieux, Basingstoke, UK) or the M.I.C Evaluator strip (ThermoFisher Scientific, Waltham, MA, USA). A limitation of such methods is that definitive MICs often cannot be determined due to the pre-defined concentration range of the test strip; with the highest concentration for clindamycin being $256 \mathrm{mg} / \mathrm{L}$. Indeed, even for gold-standard methods such as agar incorporation MIC testing, antimicrobial concentrations are doubling dilutions, often with $256 \mathrm{mg} / \mathrm{L}$ as the highest concentration; drug solubility often limits the testing of higher concentrations for many agents. Clindamycin resistant $C$. difficile with MICs of 16 to $>256 \mathrm{mg} / \mathrm{L}$ often possess the erythromycin ribosomal methylase B, encoded by erm(B), which is often located on mobile genetic elements [27,28] and for which there are multiple genetic organisations but no clear ribotype association [12]. Erm(B) confers clindamycin resistance via methylation of bacterial 23S rRNA, and consequent prevention of drug binding and antimicrobial activity. However, clindamycin-resistant $\operatorname{erm}(\mathrm{B})$ negative, and clindamycin-susceptible erm(B) positive $C$. difficile have 
been reported [29]; thus, alternative mechanisms of resistance such as erm(B)-independent 23S rRNA methylation [12], efflux, or other unidentified mechanisms may be present in C. difficile.

\subsection{Erythromycin}

Erythromycin is a macrolide antimicrobial agent that inhibits protein synthesis in bacteria by binding the 50S ribosomal subunit and impairing the elongation cycle by preventing movement of the ribosome along the mRNA. Macrolides are not considered antimicrobial agents that have a strong association with CDI, although true risk data are difficult to obtain given that macrolides are often co-administered with other antibiotics; for example, with penicillins in the treatment of community-acquired pneumonia. C. difficile may be resistant to erythromycin via expression of erm(B) [12,30] or erm(FS) [31], methylation of 23S rRNA (erm(B)-independent) [12], mutation in 23S rDNA (C656T substitution in high-level erythromycin resistant and low-level clindamycin resistant, erm(B) negative C. difficile) [31], and a potential role for the cme efflux pump [32]. Similar to clindamycin, resistance to erythromycin varies within, and between RT and is characterised by MICs $\geq 8 \mathrm{mg} / \mathrm{L}$ (CLSI). In a recent study in Korea, of 1407 non-duplicated $C$. difficile isolates collected over 10 years, resistance (MICs 32 to >128) was seen in 3/4 of the most prevalent RT $(001,018$, and 017$)$, and in $80 \%$ of all C. difficile isolates [14]. Erythromycin resistance has also been demonstrated in hypervirulent RT027 [10,13,21] and 078 [33], and other prevalent RT such as 001 [10,21,34], and 017 [15]. There are 17 distinct genetic organisations of erm(B) (E1-E17) reported in C. difficile [12]. Erythromycin resistant $C$. difficile (erm(B) positive) appear to demonstrate reduced fitness in vitro in competition assays with susceptible strains, and in growth rate experiments [35]; whether such reduced fitness/virulence is present in vivo remains to be determined.

\subsection{Tetracyclines}

Tetracyclines inhibit protein synthesis by preventing the attachment of aminoacyl-tRNA to the ribosomal acceptor (A) site [36]. This family of antimicrobials is considered low-risk for induction of CDI, despite broad Gram-positive, Gram-negative, and anti-anaerobe spectra of activity. Tetracycline resistance in $C$. difficile was documented over 30 years ago and was demonstrated as transferable between $C$. difficile strains [37,38] and also other bacterial species [39]. Resistance to tetracyclines also varies widely between countries and with RT. In an ESGCD study in 2007, Barbut and colleagues observed no tetracycline resistant $C$. difficile in isolates from the UK and the Netherlands, $14.3 \%$ resistance in isolates from Poland, $21.4 \%$ resistance in isolates from Hungary, and $38.9 \%$ resistance in isolates from Greece; compared to $9.2 \%$ across the entire study [40]. In general, most susceptibility studies demonstrate resistance in $<10 \%$ of isolates. The current CLSI breakpoint for resistance to tetracycline is $\geq 16 \mathrm{mg} / \mathrm{L}$ and obtaining definitive MICs is dependent on whether E-test or equivalent tests are used (maximum concentration $32 \mathrm{mg} / \mathrm{L}$ ) or agar/broth MIC testing using doubling dilution concentrations. Tetracycline intermediate resistance (MIC $8 \mathrm{mg} / \mathrm{L}$ ) has been demonstrated in RTs 014 , 017, 078 [33,40], resistance (MIC $\geq 16 \mathrm{mg} / \mathrm{L}$ ) in RTs 012 and 048 [12], and higher-level resistance (MICs 32 to $>256 \mathrm{mg} / \mathrm{L}$ ) reported in 32 isolates of RT012 from Sweden [41] and in an additional comparative study of isolates from Shanghai and Sweden (MICs up to $64 \mathrm{mg} / \mathrm{L}$ ) [15]. Resistance to tetracyclines may be mediated by efflux proteins, ribosomal protection mechanisms, or via enzymatic inactivation of the antimicrobial [36]. In C. difficile tetracycline resistance most often manifests as a 
consequence of TetM production but may also be due to TetW [42,43]. Both TetM and TetW are cytoplasmic proteins with homology to elongation factors (EF-Tu and EF-G) that protect ribosomes from the action of tetracyclines by reducing their susceptibility to the antimicrobial [36]. The tet genes in C. difficile are carried on transposons related to Tn916 [44,45], i.e., Tn5397 [44,46], Tn6190 [47], Tn6235 [48]. Spigaglia and colleagues demonstrated the concurrent presence of tet $M$ and tet $W$ in three isolates of RT048 and one RT012 [12], yet it is unclear if expression of both tet elements elicits any further reduction in tetracycline MIC. Using a MIC breakpoint of $\geq 8 \mathrm{mg} / \mathrm{L}$ to examine human and pig isolates from the Netherlands and UK, 75/102 human strains and 15/56 porcine strains were resistant to tetracycline [49]. All tetracycline-resistant strains contained the Tn916-like transposon harbouring the tet(M) gene. DNA fingerprinting of strains demonstrated relatedness of porcine and human strains, which is notable given the widespread use of tetracyclines in animal husbandry [49].

\subsection{Linezolid}

Linezolid is an oxazolidinone that is active against Gram-positive bacteria by inhibition of protein synthesis via targeting of bacterial 23S rRNA [50]. Linezolid is not currently used to treat CDI, but can inhibit exotoxin production in Gram positive cocci [51,52], has good activity against $C$. difficile including strains with reduced susceptibility to metronidazole [53-55], and inhibits cytotoxin production in complex in vitro models of CDI [53]. Although most $C$. difficile strains are inhibited by linezolid at concentrations far below the CLSI breakpoint for resistance ( $>4 \mathrm{mg} / \mathrm{L})$, sporadic isolates with MICs of $8-16 \mathrm{mg} / \mathrm{L}$ have been reported [53,56,57]. Baines and colleagues observed two $C$. difficile (RT023 and RT067) with MICs of $8 \mathrm{mg} / \mathrm{L}$ in a study of 118 C. difficile isolates; further testing of 27 RT023 isolates yielded no further resistant isolates [53]. Further analysis of the two linezolid resistant isolates by PCR and sequencing did not demonstrate mutations in 23S rRNA (unpublished data). A recent study of 891 clinical isolates of toxigenic $C$. difficile yielded 9 isolates with elevated MICs (6-16 mg/L, RT001 (2/9), RT017 (6/9), and RT078 (1/9)) and PCR and sequencing identified the presence of $c f r$, which encodes a rRNA methyltransferase, in 7/9 C. difficile isolates on Tn6218, but not in the two RT001 isolates [56].

\section{DNA and DNA/RNA Accessory Enzyme Inhibitors}

\subsection{Fluoroquinolones}

Fluoroquinolones are synthetic derivatives of the naphthyridone molecule nalidixic acid, and were developed to increase inhibition of target molecules and broaden the antimicrobial spectrum [58]. Fluoroquinolones such as ciprofloxacin and moxifloxacin target DNA gyrase; specifically gyr $A$ and gyr $B$ in $C$. difficile, which encode the $\mathrm{A}$ and $\mathrm{B}$ subunits of the enzyme responsible for supercoiling bacterial DNA. Resistance to fluoroquinolones is well documented in $C$. difficile usually due to alterations in target structure via nucleotide substitutions ( $g y r A$ and/or $g y r B$ ) [6,12,59-62] within the quinolone-resistance determining region (QRDR) of DNA gyrase subunits; the role of efflux mediated resistance in $C$. difficile is unclear $[12,63]$. Considerable variability exists in $C$. difficile fluoroquinolone susceptibility within RT and between countries, with certain RT which are currently circulating being uniformly resistant to fluoroquinolones. The breakpoints for ciprofloxacin and moxifloxacin resistance are $\geq 32 \mathrm{mg} / \mathrm{L}$ (EUCAST ECOFF) and $\geq 8 \mathrm{mg} / \mathrm{L}$ respectively. A European prospective susceptibility testing 
surveillance programme (ClosER) recently reported 2011-2012 results; 40\% of 953 C. difficile were resistant to moxifloxacin, in multiple RTs, especially RT027 and RT356 [9]. Higher-level resistance to moxifloxacin is usually characterised by MICs $\geq 32 \mathrm{mg} / \mathrm{L}$, with lower-level resistance eliciting MICs of 8-16 mg/L; specific mutations within DNA gyrase subunits are associated with the magnitude of resistance. In a European surveillance study in 2008, Asp426-Val in gyrB was associated with high-level resistance to moxifloxacin [64], whereas in subsequent studies the same mutation was present in strains with only low-level resistance [14,65]; such observations suggest that other factors can influence resistance, possibly coupled with differences in gene expression. $C$. difficile strains may possess two concurrent substitutions in either gyrase gene, or a concurrent mutation in both gyrA and gyrB [65], however multiple concurrent mutations in both gyrase subunit genes have not been reported. Thr82-Ile is the most common gyrA substitution but Asp71-Glu, Pro116-Ala, Ala118-Ser, and Thr82-Ala also have been reported [12,64-68]. Mutations within gyrB may involve Asp426-Val, Asp426-Asn, Glu466-Val, Ser366-Ala, Leu444-Phe [12,14,59,64,65]. The acquisition of the Thr82-Ile gyrA substitution, in a clinical environment where fluoroquinolone use was substantial in the 1990-2000s [69], was a pivotal factor in the emergence of RT027 in the USA and Canada [6]. A recent whole genome sequencing and phylogenetic analysis of RT027 identified that the much highlighted changes in the PaLoc of C. difficile that were initially postulated as responsible for RT027 hypervirulence and transmission, were in fact present in pre- and post-epidemic RT027; yet the acquisition of fluoroquinolone resistance was the defining moment of the evolution and spread of the two lineages of this RT [6].

\subsection{Rifamycins}

The rifamycins achieve selective toxicity in bacteria by targeting bacterial DNA-dependent RNA polymerase. Rifamycins (rifampicin and rifaximin) have been used to treat CDI due to very low MICs in (susceptible) C. difficile; rifaximin (but not rifampicin) is poorly absorbed after oral administration [70]. Rifampicin resistance in $C$. difficile has been reported in $0-17.5 \%$ of isolates $[9,11,12,15,17,71,72]$ at a breakpoint of $\geq 16 \mathrm{mg} / \mathrm{L}$, with resistant isolates seen in 17/22 countries in a recent pan-European study [9]. High prevalence of resistant isolates was observed in Italy (particularly RT018 and RT356), the Czech Republic, Denmark, and Hungary, with resistant isolates in RTs 017, 027, 176, and 001/072 observed [9]. In a study of 80 clinical $C$. difficile isolates, O'Connor et al observed seven $\operatorname{rpo}(B)$ substitutions (14 C. difficile strains): Arg505-Lys, His502-Asn, -Tyr, -Arg, Ser488-Thr, Asp492-Asn, and Iso548-Met; therefore, several distinct substitutions, some at the same location, are associated with MICs $>256 \mathrm{mg} / \mathrm{L}$ [71]. There is a bimodal distribution of rifampicin MICs in C. difficile, typically with results $\leq 0.016 \mathrm{mg} / \mathrm{L}$ and $>256 \mathrm{mg} / \mathrm{L}$ [41]. Spigaglia et al. observed mutations in the $\beta$-subunit of RNA polymerase, encoded by rpo(B) (1 or 2 substitutions); specifically His502-Asn and Arg505-Lys (92\% of resistant strains), Arg505-Lys alone (6\% of resistant isolates), or His502-Asn alone (2\% of isolates) [12]. Rifampicin resistance has been reported in multiple epidemic and non-epidemic RTs [12,22,72], including in multi-drug-resistant (MDR) strains. Mutations in rpo(B) between positions 488-548 may either disrupt the direct interaction between rifamycins and RpoB, or modify the rifamycin-binding pocket and therefore reduce the affinity of target for the antimicrobial [72,73]. Resistance has been described during treatment of CDI with rifamycins [74-76]. A RT056 isolate with a baseline rifaximin MIC of $0.002 \mathrm{mg} / \mathrm{L}$ became resistant (MIC $\geq 32 \mathrm{mg} / \mathrm{L}$; His502-Tyr substitution) within 3 days of 
rifaximin therapy [76]. A second substitution (Pro496-Ser) was also identified in a second RT056 isolate and both strains persisted for 49 days, following which the patient was treated with fidaxomicin; the isolate reverted to being rifaximin-susceptible, and the patient remained asymptomatically colonised for $>30$ days [76].

\subsection{Fidaxomicin}

Fidaxomicin was the first new therapy to be licensed for the treatment of CDI in over 25 years; it is now recommended for use in initial or recurrent episodes of CDI [77]. Fidaxomicin is a macrocyclic narrow spectrum, bactericidal antimicrobial agent, which is poorly absorbed after oral administration, and targets bacterial RNA polymerase at a site distinct from rifamycins [78,79]. Fidaxomicin is very active against $C$. difficile, with MICs generally $0.02-0.25 \mathrm{mg} / \mathrm{L}$ [9]. Rare reports exist of fidaxomicin reduced susceptibility (MIC 2-4 mg/L) [80,81] or resistance (MIC $16 \mathrm{mg} / \mathrm{L}$ ) [82]. However, even these higher MICs are approximately two orders of magnitude lower than the concentrations of fidaxomicin that are achieved in the gut lumen. Leeds et al. conducted laboratory studies exposing $C$. difficile to sub-inhibitory concentrations of fidaxomicin over 10 serial passages, with whole genome sequencing to characterise resistance mechanisms, and demonstrated a Glu-Arg nucleotide substitution at position 1073 in $r p o(B)$ or mutation within CD22120 (a marR homolog); resulting in a fidaxomicin MIC of $4 \mathrm{mg} / \mathrm{L}[81]$.

\subsection{Metronidazole}

Metronidazole achieves its antibacterial action by directly damaging bacterial DNA following reduction of its nitro group once inside a bacterium. Several reduction systems have been highlighted as important for the activation of metronidazole, but perhaps most important is the pyruvate-ferredoxin/ flavodoxin oxidoreductase (PFOR) system; pyruvate is decarboxylated to acetyly-CoA and concurrently electrons are transferred to the nitro group of metronidazole by ferredoxin or flavodoxin [83]. Metronidazole has been a primary treatment option for CDI for over 30 years. However, reduced efficacy was reported by Musher et al. [84] in a prospective observational study of 207 CDI patients, in which only $50 \%$ of patients were successfully treated, and $22 \%$ continued to experience symptomatic CDI despite $\geq 10$ days of treatment. Furthermore, $28 \%$ of patients experienced symptomatic recurrence within 90 days. Similar observations of reduced initial response to metronidazole and increased CDI recurrence have also been reported elsewhere [85].

Freeman and colleagues recently demonstrated that only $0.11 \%$ of $953 \mathrm{C}$. difficile were resistant to metronidazole (MIC $\geq 8 \mathrm{mg} / \mathrm{L}$ ), with maximal MICs of $8 \mathrm{mg} / \mathrm{L}$ observed in a single RT106 isolate from the UK [9]. Interestingly, 20 isolates demonstrated reduced susceptibility to metronidazole (MIC $4 \mathrm{mg} / \mathrm{L}$ ), of which 55\% were RT027, isolated from the UK, Switzerland, Poland, Denmark, Germany, Denmark, the Czech Republic, and Hungary. Reduced susceptibility to metronidazole was reported in UK C. difficile RT001 (but not RT106 or RT027) in 2008 [86], but the clinical significance of this phenotype and the underlying mechanism is uncertain. RT027, RT106, and RT001/072 (and RT356) demonstrate elevated geometric mean metronidazole MICs compared with other RTs [9]. Metronidazole-resistant C. difficile have been reported in other studies [87-90] and resistance has been reported as heterogeneous, with slow-growing metronidazole resistant $C$. difficile within a population observed after extended 
incubation periods using E-test [91]. It is important to note that the choice of MIC methodology is crucial to the detection of reduced susceptibility to metronidazole; E-tests in particular under-estimate the MIC of metronidazole [86,92].

Despite reports of reduced susceptibility/resistance to metronidazole, and modest faecal concentrations of metronidazole (approximately $9 \mathrm{mg} / \mathrm{L}$ ), CDI treatment failure has not been linked to antimicrobial resistance in C. difficile [93]. Until recently, mechanisms of metronidazole resistance in C. difficile have remained elusive; resistant strains have not been described with nimA-J [94,95], which codes for the reduction of the nitro group of nitroimidazoles into a poorly active amine group [96]. Three recent studies have provided important information regarding metronidazole resistance in C. difficile [97-99]. Lynch et al. used comparative whole genome sequencing to analyse a stable metronidazole-resistant RT027 strain and a clone that reverted to metronidazole-susceptible after freeze-thawing [98]. In addition to point mutations within sporulation $(\operatorname{spo} 0 A)$ and germination $(\operatorname{csp} C)$ loci, the authors demonstrated mutations in the ferric uptake regulator ( $f u r$ ), a mutation in a putative nitroreductase gene (in both RT027 strains), and a mutation in the corporphyrinogrn III oxidase gene (hemN) (Table 1). In a subsequent proteomic analysis of the same RT027 strains, there was no evidence of involvement of deficiencies in the PFOR system [97]. However, the authors did observe increased production of the ferric uptake regulator protein in the metronidazole-resistant RT027; Fur is a central regulator of iron homeostasis in bacteria. Moura and colleagues analysed a metronidazole-resistant RT010 C. difficile strain using a quantitative proteomic approach on mid-log-phase cultures [99]. No aberrations in PFOR, hemN, fur, or nim were detected, but an absence of ferritin was observed in the metronidazole-resistant isolate when exposed to metronidazole; therefore deficient iron storage was postulated. Additionally, reduced ferredoxin reduction, and consequently metronidazole activation, was postulated due to the significant decreased expression of butyryl CoA dehydrogenase during metronidazole exposure [99]. It should be noted that RT010 are generally non-toxigenic; also, transfer of metronidazole reduced susceptibility or resistance between $C$. difficile strains has not been demonstrated.

Table 1. Mutations potentially contributing to reduced susceptibility and/or resistance to metronidazole (MTZ) in C. difficile.

\begin{tabular}{ccc}
\hline $\begin{array}{c}\text { Gene/Protein } \\
\text { implicated }\end{array}$ & Potential Contribution to Metronidazole Resistance & Ref. \\
\hline $\begin{array}{c}\text { Ferric uptake regulator } \\
(\text { fur })\end{array}$ & $\begin{array}{c}\text { Point mutation could lead to altered binding of Fur to SOD therefore } \\
\text { reduced oxidative stress in } C \text {. difficile in response to MTZ exposure. }\end{array}$ & {$[97,98]$} \\
\hline $\begin{array}{c}\text { Putative nitroreductase } \\
\text { Foproporphyrinogen III } \\
\text { Oxidase }(\text { hem } N)\end{array}$ & $\begin{array}{c}\text { Frameshift mutation could disrupt heme biosynthesis/metabolism, } \\
\text { defective electron transport and reduced MTZ activation. }\end{array}$ & {$[98]$} \\
\hline Ferritin & Absence in MTZ $Z_{\mathrm{R}}$ strain under MTZ pressure \\
therefore deficient iron storage & {$[99]$} \\
\hline Butyryl CoA & $\begin{array}{c}\text { Significant reduction under MTZ pressure, therefore possible reduced } \\
\text { ferredoxin reduction and consequent reduction in MTZ activation. }\end{array}$ & {$[99]$} \\
\hline dehydrogenase (Bcd) & $\begin{array}{c}\text { Reduced expression in MTZ } \mathrm{R} \text { and revertant strains, possible reduction } \\
\text { in MTZ activation. Another ferredoxin protein was increased in } \\
\text { expression in MTZ }\end{array}$ & {$[97]$} \\
Ferredoxin and revertant strains. Unclear significance. & \\
\hline
\end{tabular}

$\mathrm{MTZ}_{\mathrm{R}}=$ metronidazole-resistant $C$. difficile. 


\section{Cell Wall Synthesis Inhibitors}

\subsection{Vancomycin}

Much like metronidazole, vancomycin has been a first-line therapy for CDI for the past 3 decades; vancomycin concentrations typically exceed $1000 \mathrm{mg} / \mathrm{L}$ in faeces after oral administration. Vancomycin retains good activity against $C$. difficile, including against strains with reduced metronidazole susceptibility and also epidemic strains that tend to have higher geometric mean metronidazole MICs. Vancomycin binds to the C-terminal dipeptide, D-alanyl-D-alanine, of the NAM-pentapeptide of peptidoglycan (PG) precursors during PG synthesis, so preventing transpeptidation (cross-linking) reactions between adjacent peptide side chains of adjacent PG strains. Acquired resistance to vancomycin is well studied in Staphylococcus aureus and Enterococcus spp. and results from expression of one of 9 van gene clusters, which encode ligase enzymes that modify the terminal D-ala-D-ala of PG precursors [100]. The expression of vancomycin resistance is controlled by a 2-component regulatory system (VanSR). C. difficile has been shown to possess a van $G$ homolog [101,102] within its genome (van $G_{C d}$ ), which was recently assessed for its ability to confer vancomycin resistance. van $G_{C d}$ is inducible by vancomycin, but does not promote vancomycin resistance in $C$. difficile. When van $G_{C d}$ was cloned into a vancomycin-susceptible Escherichia coli strain, vancomycin resistance was conferred; therefore, it was postulated that there is some mechanism in C. difficile that prevents expression of vancomycin resistance [100]. Susceptibility to vancomycin was recently demonstrated in $97.8 \%$ of 953 C. difficile isolates ( $\mathrm{MIC} \leq 2 \mathrm{mg} / \mathrm{L}$ ). Reduced susceptibility to vancomycin has begun to emerge over the past 5 years (i.e., MICs $\geq 4 \mathrm{mg} / \mathrm{L}$ ), but remains relatively sporadic. Recently, single isolates with intermediate-resistance (MIC $4 \mathrm{mg} / \mathrm{L}$ ) have been seen from the Czech Republic, Ireland, Latvia, and Poland, and multiple isolates from Italy and Spain, resistant to vancomycin (MIC $\geq 8 \mathrm{mg} / \mathrm{L}$ ), from multiple ribotypes (including RT027, RT126, RT356, and RT001/072) have been detected. No underlying mechanisms for such reduced susceptibility have been reported [9]. The authors of this study also commented that RT018 and RT356 (which are prevalent in Italy [9]) demonstrated notably higher vancomycin geometric mean MICs $(2.00 \mathrm{mg} / \mathrm{L}$ and $2.28 \mathrm{mg} / \mathrm{L}$, respectively) than other common ribotypes $(0.62-0.95 \mathrm{mg} / \mathrm{L})$. In a Swedish study, Noren and colleagues observed three RT002 isolates with vancomycin MICs $4-8 \mathrm{mg} / \mathrm{L}$ over a 2 year period in a patient who underwent long-term IV vancomycin therapy for $S$. aureus septicaemia [41].

\subsection{Penicillins}

Broad spectrum $\beta$-lactam antimicrobial agents are well recognised for their propensity to induce CDI, e.g., aminopenicillins and cephalosporins. Conversely, some $\beta$-lactams when given as combination products with $\beta$-lactamase inhibitors, e.g., piperacillin-tazobactam, are not noted for their propensity to induce CDI, and indeed have been used in preference to cephalosporins to reduce CDI rates $[103,104]$. $C$. difficile susceptibility to $\beta$-lactams varies depending on the antimicrobial, with general susceptibility to $\beta$-lactam- $\beta$-lactamase inhibitor combinations, resistance to cephalosporins (although small numbers may be susceptible), and intermediate resistance or susceptibility to aminopenicillins. Noren et al. reported penicillin V and piperacillin MIC 90 of $8 \mathrm{mg} / \mathrm{L}$ and $32 \mathrm{mg} / \mathrm{L}$, respectively, in C. difficile isolates from Sweden over a 15 year period, with some isolates demonstrating high-level resistance $(>256 \mathrm{mg} / \mathrm{L})$ [41]. 


\section{Antimicrobial Susceptibility of the Indigenous Gut Microflora}

From early in vitro experiments exploring colonisation resistance [105], and its association with antimicrobial therapy [106], it was clear that the indigenous gut microflora played a pivotal role in gut homeostasis and the prevention of CDI. A new antimicrobial agent to treat CDI should be: (1) assessed for its propensity to disrupt the indigenous gut microflora such that CDI may emerge; (2) as narrow spectrum as possible, ideally $C$. difficile specific; and (3) have a favourable pharmacokinetic/pharmacodynamic profile. Researchers have assessed in vitro and in vivo the effects of antimicrobial agents commonly linked to CDI; measured endpoints include which populations of the indigenous gut microflora are adversely affected or are promoted, whether $C$. difficile can be isolated and what is the duration of toxin production following spore germination [53,62,105,107-124]. Identifying a small number of key bacterial groups responsible for colonisation resistance to CDI in amongst over 500 bacterial species in the human colon is obviously an extremely challenging feat, but one that has been attempted for over two decades [105,125-127]. Recent research into selective microbial restoration therapy [128] and feacal microflora transplantation (for review see [129]) has demonstrated positive outcomes in the treatment of CDI. However, to design optimal interventions that are targeted at CDI, and also to minimise the risk of selection of $C$. difficile, further research is needed to delineate which are the critical microbial factors in disease pathogenesis. Recurrent CDI occurs in approximately $20 \%$ of CDI cases following treatment with metronidazole or vancomycin, and this remains a key goal for improving therapeutic outcomes.

\subsection{Antimicrobial Agents Associated with CDI Induction}

Antimicrobial agents most commonly associated with CDI cause a shift from an anaerobe-dominated gut microflora in favour of facultative-anaerobes. Within the indigenous gut microflora, alterations in the community structure may occur over time in response to diet, stresses, antimicrobial agent exposure, and age, but the total concentrations of microbes remain relatively constant. The changes in gut microflora community structure associated with the administration of selected antimicrobial agents are presented in Table 2. From these in vitro and in vivo studies it is clear that antimicrobial agents that are potent inducers of CDI elicit widespread reductions in the anaerobic microflora, particularly Bacteroides spp. and Bifidobacterium spp., with a concurrent increase in certain populations of facultative anaerobes either during or after antimicrobial dosing, e.g., Enterococcus spp. and lactosefermenting Enterobacteriaceae. 
Table 2. Changes in selected indigenous gut microflora populations following exposure to antimicrobial agents in vitro and in vivo.

\begin{tabular}{|c|c|c|c|c|c|c|}
\hline & \multirow[b]{2}{*}{ Antimicrobial Agent } & \multicolumn{2}{|c|}{ Negatively Impacted Populations } & \multicolumn{2}{|c|}{ Positively Impacted Populations } & \multirow{2}{*}{ Refs } \\
\hline & & Anaerobes & Facultative Anaerobes & Anaerobes & Facultative Anaerobes & \\
\hline \multirow{5}{*}{$\begin{array}{l}\text { Common inducers } \\
\text { of CDI }\end{array}$} & Clindamycin & $\begin{array}{c}\text { Bifidobacteria, Bacteroides, } \\
\text { Eubacteria, Clostridia }\end{array}$ & Lactobacilli & No effect & Enterobacteria, Enterococci & $\begin{array}{c}{[53,107,110-112,} \\
114,117,130]\end{array}$ \\
\hline & Ciprofloxacin & $\begin{array}{c}\text { Anaerobes overall, Bifidobacteria, } \\
\text { Bacteroides spp., Clostridia }\end{array}$ & $\begin{array}{c}\text { E. coli }(\mathrm{LFE}), \\
\text { Lactobacilli, Enterococci }\end{array}$ & No effect & Enterococci (PD) & {$[62,131]$} \\
\hline & Moxifloxacin & $\begin{array}{c}\text { Bifidobacteria, Bacteroides fragilis } \\
\text { group, Clostridia }\end{array}$ & LFE, Enterococci & No effect & Enterococci (PD) & {$[62]$} \\
\hline & Levofloxacin * & $\begin{array}{c}\text { Bifidobacteria, Bacteroides fragilis } \\
\text { group }\end{array}$ & $\begin{array}{l}\text { LFE, Enterococci, } \\
\text { Lactobacilli }\end{array}$ & No effect & Facultative anaerobes overall & {$[62]$} \\
\hline & Co-amoxyclav & $\begin{array}{c}\text { Bifidobacteria, Bacteroides fragilis } \\
\text { group, Clostridia }\end{array}$ & No effect & No effect & Enterococci, LFE & {$[132]$} \\
\hline \multirow{4}{*}{$\begin{array}{c}\text { Infrequent } \\
\text { inducers of CDI }\end{array}$} & Piperacillin tazobactam & Bifidobacteria, Anaerobic cocci & Lactobacilli, Enterococci & No effect & Enterococci, Lactobacilli, Clostridia (PD) & [133] \\
\hline & Piperacillin tazobactam & $\begin{array}{c}\text { Anaerobes overall, Bifidobacteria, } \\
\text { Bacteroides fragilis group, }\end{array}$ & Lactobacilli, LFE, & No Effect & Enterococci, Lactobacilli, Clostridia (PD) & {$[108]$} \\
\hline & Mecillinam & Bifidobacteria & LFE & No effect & No effect & [113] \\
\hline & Erythromycin & $\begin{array}{c}\text { Bifidobacteria, Bacteroides, } \\
\text { Clostridia }\end{array}$ & $\begin{array}{c}\text { E. coli, Streptococci, } \\
\text { Lactobacilli, Enterococci }\end{array}$ & Eubacteria & No effect & [134] \\
\hline
\end{tabular}

PD, post-dosing; LFE, lactose-fermenting Enterobacteriaceae. Underlined bacterial groups were substantially reduced ( $\geq 3$-log 10 cfu/mL). * $1 / 2$ experiments, second experiment demonstrated a reduced antimicrobial effect. 
Culture-independent techniques have supplemented the data generated from culture-based studies. In a study of the intestinal microbiota of $25 \mathrm{CDI}$ patients compared with those for 50 matched controls, Manges et al., used 16S rRNA microarray to show that the Bacteroidetes and Firmicutes phyla were associated with development of CDI [135]. Lactobacillus and Clostridium are two important members of the Firmicutes phylum. Additionally, Antharam and colleagues recently reported the results of a study of 39 CDI patients ( $v s .36$ non-CDI diarrhoea patients, and 40 controls), assessing the gut microflora composition, using culture-independent 454 16S rRNA Pyrosequencing [136]. The study reported marked decreases in microbial diversity and species richness, principally due to reduced Firmicutes phylum sequence reads. Furthermore, associations between the depletion of Ruminococcaceae, Lachnospiraceae, and butyrogenic bacteria in the gut microbiota and nosocomial diarrhoea, including CDI were noted [136].

Such changes in gut microflora community structure, based on viable count data, correlate well with susceptibility studies and the concentrations of antimicrobial agent that are observed in faeces following dosing (Tables 2-4). Bifidobacterium spp. are in general susceptible to penicillins, macrolides, glycopeptides, and fluoroquinolones, but variations between species are observed [137]. Some Bifidobacterium spp. possess resistance determinants such as tetW [138], and erm(X) [139] to confer resistance to tetracyclines and erythromycin/clindamycin, respectively. Bacteroides spp. vary in susceptibility to co-amoxiclav, with $\mathrm{MIC} 90 \mathrm{~s}$ ranging from 4 to $>128 \mathrm{mg} / \mathrm{L}$ [140] and also vary substantially in their susceptibilities to fluoroquinolones [140,141]. Stiefel et al. raised an interesting hypothesis that antimicrobial-resistant gut microflora may be protective in the gut when a patient is exposed to antimicrobial agents [142]. A cephalosporinase-producing Bacteroides thetaiotamicron was dosed orally into mice for 3 days, prior to administration of subcutaneous ceftriaxone and oral $C$. difficile spores, and showed that prior colonisation with the B. thetaiotamicron strain inactivated intra-intestinal cephalosporin and also prevented overgrowth by $C$. difficile [142]. If key protective bacterial species within the human colon were resistant to antimicrobial agents that were active in the induction of CDI, this may potentially stabilise host colonisation resistance, although possible transfer of resistance determinants to pathogenic bacterial species is an obvious concern. In a novel recent study assessing antimicrobial-induced gut microflora changes in mice and resultant susceptibility to CDI development, and correlating changes in gut microflora in hospitalized patients, Buffie and colleagues suggested that Clostridium scnidens may be a key protective species against CDI [143].

\subsection{Antimicrobial Agents to Treat CDI: Metronidazole, Vancomycin, and Fidaxomicin}

Treatments for CDI also may adversely affect the indigenous gut microflora and therefore prolong the perturbation of the microflora; thus, putting an individual at risk of recurrent CDI either because persistent spores may germinate (CDI relapse) or if a new strain is acquired (CDI re-infection). The reduced efficacy of metronidazole may be to be due to a perturbed microflora $[85,110,144-146]$ that is exacerbated by the CDI treatment drug, reduced or heterogeneous susceptibility to metronidazole in clinical $C$. difficile [86,91], and/or host factors including immunoresponsiveness to $C$. difficile and its toxins [147]. Mean metronidazole concentrations in faeces range from $0-26 \mathrm{mg} / \mathrm{kg}$ (approx. mg/L) [123,144,148-150] (Table 4) and levels decline as the colonic mucosal inflammation resolves [148]; therefore, only low, possibly sub-therapeutic, antibiotic concentrations may be present, 
leading to inconsistent treatment outcomes. Assuming a supra-MIC of metronidazole, bactericidal activity may be demonstrated against key anaerobic gut microflora groups (Bifidobacterium spp. and Bacteroides spp.) and this, combined with rapid decline of antimicrobial concentration following cessation of dosing (i.e., washout), may allow C. difficile to compete for key nutrients [102] that are needed for growth and toxin production leading to recurrent infection.

Table 3. Changes in selected indigenous gut microflora populations following exposure to CDI therapeutic antimicrobial agents in vitro and in vivo.

\begin{tabular}{cccccc}
\hline \multirow{2}{*}{$\begin{array}{c}\text { Antimicrobial } \\
\text { Agent }\end{array}$} & \multicolumn{2}{c}{ Negatively Impacted Populations } & Positively Impacted Populations & \multirow{2}{*}{ Refs } \\
\cline { 2 - 4 } Anaerobes & $\begin{array}{c}\text { Facultative } \\
\text { Anaerobes }\end{array}$ & Anaerobes & $\begin{array}{c}\text { Facultative } \\
\text { Anaerobes }\end{array}$ & \\
\hline \multirow{2}{*}{$\begin{array}{c}\text { Vancomycin } \\
\text { Bifidobacteria, } \\
\text { Betronidazole }\end{array}$} & $\begin{array}{c}\text { Bactobacilli, } \\
\text { Enterococci }\end{array}$ & No effect & $\begin{array}{c}\text { LFE PD. } \\
\text { Lactobacilli (PD) }\end{array}$ & {$[111,151]$} \\
\hline Bacteroides, Clostridia & $\begin{array}{c}\text { No effect (one study } \\
\text { E. coli) }\end{array}$ & No effect & LFE & {$[110,152]$} \\
\hline Fidaxomicin & Bifidobacteria & Enterococci & No effect & LFE & {$[146]$} \\
\hline
\end{tabular}

PD, post-dosing; LFE, lactose-fermenting Enterobacteriaceae. Underlined bacterial groups were substantially reduced $\left(\geq 3-\log _{10} \mathrm{cfu} / \mathrm{mL}\right)$. ${ }^{+}$In studies where bioactive metronidazole was detected.

Very high vancomycin levels occur in faeces following oral administration (1345-1406 mg/L) [123,150]. In healthy volunteers this results in marked reductions in Enterococcus spp. and Bacteroides spp., and increased numbers of facultatively-anaerobic Gram-negative bacilli (Klebsiella spp., Citrobacter spp., and Enterobacter spp.) [151]. Previous investigations also indicated the emergence of intrinsically-resistant Gram-positive bacteria during vancomycin therapy [151,153]. Instillation of vancomycin in a human in vitro gut model reported similar alterations in bacterial community structure [114]. Vancomycinsusceptible Gram-positive bacterial groups (bifidobacteria and enterococci) were markedly reduced, while intrinsically-resistant Gram-positive groups such as lactobacilli and pediococci increased in number [114]. Interestingly, a marked reduction in Bacteroides spp. was demonstrated following vancomycin administration, in accordance with the observations of Edlund and colleagues [151]. Citron et al. demonstrated susceptibility to vancomycin in seventeen isolates of $B$. fragilis with MICs ranging from $16-128 \mathrm{mg} / \mathrm{L}$; thus, very high concentrations of this anti-Gram-positive antibiotic are sufficient to adversely affect Gram-negative populations such as Bacteroides spp. [55].

Sears et al. analysed 175 faecal specimens from CDI patients who underwent a $200 \mathrm{mg}$ twice-daily dose of fidaxomicin for 10 days and reported a mean $( \pm \mathrm{SE})$ faecal concentration of $1396 \mathrm{mg} / \mathrm{kg}$ $( \pm 77.0)$ [154]. An active metabolite of fidaxomicin (OPT-1118) was also detected in faecal specimens and is also active against $C$. difficile. With fidaxomicin achieving such high faecal concentrations there is the potential that it may disrupt the indigenous gut microflora, even species with raised MICs. Susceptibility testing data indicated that fidaxomicin has good activity against $C$. difficile, C. perfringens, C. innocuum (MICs $<0.125 \mathrm{mg} / \mathrm{L}$ ), but also has activity against other Gram-positive bacteria such as Bacillus spp. (MIC $1 \mathrm{mg} / \mathrm{L}$ ), Enterococcus spp. (MIC $4 \mathrm{mg} / \mathrm{L}$ ), Lactobacillus casei (but not L. acidophilus) (MIC $1 \mathrm{mg} / \mathrm{L})$, Micrococcus luteus (MICs $\leq 0.06 \mathrm{mg} / \mathrm{L}$ ), Bifidobacterium spp. (MICs $\leq 0.25 \mathrm{mg} / \mathrm{L})$, and anaerobic cocci (MICs $\leq 1 \mathrm{mg} / \mathrm{L})$. Additionally, some anti-Gram-negative 
activity was demonstrated against Moraxella cattharalis (MIC $\leq 2 \mathrm{mg} / \mathrm{L}$ ) and Acinetobacter calccoaceticus (MIC $1 \mathrm{mg} / \mathrm{L}$ ) [155,156]. Conventional susceptibility data does not tell us the actual effect of fidaxomicin on the gut microflora, where indigenous microorganisms are exposed to very high antibiotic concentrations of fidaxomicin, and what the potential effect on colonisation resistance is.

Gut model and in vivo studies offer insights into the effects of CDI therapeutics on gut microflora [146,157]. In an in vitro gut model fidaxomicin is effective in treating simulated primary and recurrent CDI [146]; inhibition of Bifidobacterium spp. was seen in three of four gut model experiments and the microflora became dominated by lactose-fermenting Enterobacteriaceae. Despite these microflora changes, fidaxomicin instillation was not associated with recurrent CDI, possibly due to persistence of supra-MICs of fidaxomicin for 2-3 weeks after dosing cessation, so preventing $C$. difficile spore germination. No inhibitory activity against Bacteroides spp. was observed, as would be predicted from in vitro susceptibility testing $[155,156]$. Another way of delineating the potential for recurrent CDI associated with a therapeutic is to measure the antibiotic-mediated inhibition of $C$. difficile spore outgrowth [158].

\section{Role of $C$. difficile Antimicrobial Susceptibility in CDI Induction and Treatment}

Trying to assess the importance of the susceptibility of $C$. difficile to antimicrobial agents is not as simple as it might first appear, since CDI may result from the administration of antimicrobial agents to which the infecting strain is either susceptible or resistant. It is the timing of CDI that may differ; earlier infection may occur if a $C$. difficile strain is resistant to an antimicrobial agent. In vitro experiments with a human chemostat model of the colon clearly demonstrate $C$. difficile spore germination, outgrowth, and toxin production occur once bioactive antimicrobial concentrations decline to sub-MIC levels [110,111]. There are of course many other factors than simply antimicrobial concentrations that interplay to facilitate CDI (Figure 1).

By using a mass-balance analysis of faecal concentrations of antimicrobial agents, it is possible to predict how quickly antimicrobials will be washed out of the gut and therefore analyse the potential importance of elevated MICs (Table 4). It should be noted that these estimations assume no binding of or inactivation of the antimicrobial. Human colonic transit times vary from 20-120 h, and are often slower in the elderly $[159,160]$. Selecting an appropriate gut transit time and corresponding dilution rate ( $1 /$ transit time, $\left.h^{-1}\right)$ is complicated by the variability between subjects. For the present predictions, the gut transit time was based upon the rate of washout of vancomycin observed in the study of Abujamel et al. (vancomycin concentrations kindly supplied by Dr Curtis Donskey) [123]. By selecting a gut transit time of $35 \mathrm{~h}$ (Dilution rate $=0.029 \mathrm{~h}^{-1}$ ), washout to $<1 \mathrm{mg} / \mathrm{L}$ vancomycin would be achieved by day 11 after dosing ceased, which reflects the data published in [123] (Figure 2). Using this same method it can be calculated that for a $C$. difficile strain with a vancomycin MIC of $4 \mathrm{mg} / \mathrm{L}$, spores would be able potentially to germinate and outgrow 2 days before a strain that had an MIC of $1 \mathrm{mg} / \mathrm{L}$; i.e., day 9 vs. 11 post cessation of vancomycin dosing, assuming a faecal concentration of $1350 \mathrm{mg} / \mathrm{L}$ at the end of dosing. This may therefore provide a competitive advantage for strains with reduced vancomycin susceptibility; strains with an MIC of $8 \mathrm{mg} / \mathrm{L}$ could potentially germinate/outgrow a day earlier still.

Importantly, germination, outgrowth, and proliferation of $C$. difficile will also be part-determined by the extent of persisting colonisation resistance disruption that is either due to the original CDI inducing 
antibiotic(s) and/or the therapeutic agent. If we consider a "fidaxomicin-resistant" $C$. difficile strain with an MIC of $16 \mathrm{mg} / \mathrm{L}$, spores could germinate/outgrow 7 days after cessation of fidaxomicin dosing, whereas susceptible strains (MIC $0.06 \mathrm{mg} / \mathrm{L}$ ) would be inhibited from outgrowing until 15 days after cessation of fidaxomicin dosing if we assume concentrations in faeces were $1400 \mathrm{mg} / \mathrm{L}$ and no additional persistence due to spore binding or sequestration within gut biofilms. For metronidazole reduced susceptibility strains (MIC 4-8 mg/L) there is the possibility that luminal metronidazole concentrations during CDI therapy would be sub-MIC and therefore not inhibit $C$. difficile. If we assume that $15 \mathrm{mg} / \mathrm{L}$ of metronidazole was present at the end of a dosing regimen, then spores of $C$. difficile with MICs of 4 or $8 \mathrm{mg} / \mathrm{L}$ would be able to germinate/outgrow after 1 to 2 days following cessation of metronidazole dosing, compared to 5 days for a strain with an MIC of $0.5 \mathrm{mg} / \mathrm{L}$. Abujamel et al. commented that there was a 3 week vulnerable period for re-establishment of $C$. difficile colonization after CDI treatment with vancomycin or metronidazole [123]. This observation is consistent with predicted concentrations of vancomycin and metronidazole falling below the MIC for $C$. difficile that are susceptible to vancomycin/metronidazole.

These same principles can be applied to the other antimicrobial agents which commonly induce CDI (Table 4), with an obvious selective advantage for $C$. difficile with reduced drug susceptibility or resistance, when proliferation may occur before gut microflora colonisation resistance has normalised.

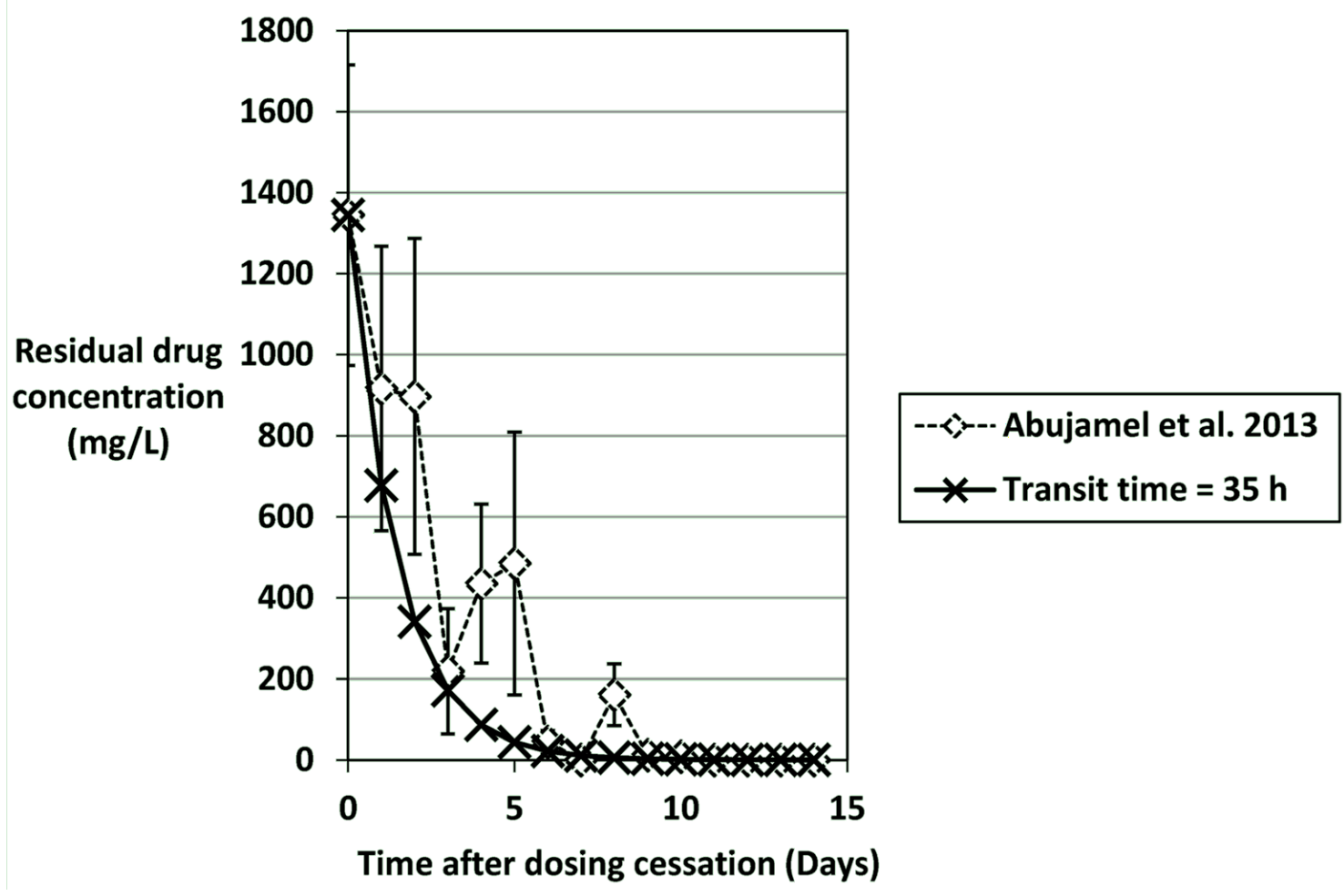

Figure 2. Predicted washout of vancomycin $(\mathrm{mg} / \mathrm{L})$ using a mass-balance calculation assuming a gut transit time of 35 hours (dilution rate $=0.029 \mathrm{~h}^{-1}$ ). Vancomycin concentrations (mean $\pm \mathrm{SE}$ ) are from Abujamel et al. $[123,161]$ and $\mathrm{mg} / \mathrm{kg}$ were assumed to equal $\mathrm{mg} / \mathrm{L}$. 
Table 4. Predicted washout of antimicrobial agents from the human colon using a mass-balance calculation assuming a gut transit time of $35 \mathrm{~h}$ (dilution rate $=0.029 \mathrm{~h}^{-1}$ ) and representative steady-state concentrations observed during antimicrobial dosing based on published data.

\begin{tabular}{|c|c|c|c|c|c|c|c|c|c|}
\hline \multirow{2}{*}{$\begin{array}{c}\text { Antimicrobial } \\
\text { Agent }\end{array}$} & \multirow{2}{*}{$\begin{array}{c}\text { Representative Steady- } \\
\text { State Concentration } \\
(\mathrm{mg} / \mathrm{L})\end{array}$} & \multicolumn{6}{|c|}{ Washout Time (days) to Achieve Residual Antimicrobial } & \multirow{2}{*}{$\begin{array}{c}\text { Faecal/bile (B) } \\
\text { Concentrations in vivo } \\
(\mathrm{mg} / \mathrm{kg})\end{array}$} & \multirow{2}{*}{ Refs } \\
\hline & & $32 \mathrm{mg} / \mathrm{L}$ & $16 \mathrm{mg} / \mathrm{L}$ & $8 \mathrm{mg} / \mathrm{L}$ & $4 \mathrm{mg} / \mathrm{L}$ & $2 \mathrm{mg} / \mathrm{L}$ & $1 \mathrm{mg} / \mathrm{L}$ & & \\
\hline Metronidazole & 15 & NR & NR & 1 & 2 & 3 & 4 & $0,9.3,26$ & {$[123,144,148,149,162]$} \\
\hline Vancomycin & 1350 & & 7 & & & & & 1345,1406 & {$[123,150]$} \\
\hline Fidaxomicin & 1400 & 6 & 7 & 8 & 9 & 10 & 11 & 1396 & {$[154]$} \\
\hline $\begin{array}{l}\text { Clindamycin } \\
\text { Ciprofloxacin }\end{array}$ & 150 & 3 & 4 & 5 & 6 & 7 & 8 & $\begin{array}{c}33.9 \text { (B), 97, 147.4, } 203.8136 .8, \\
168.5,891\end{array}$ & $\begin{array}{l}{[130,163-165]} \\
{[131,165,166]}\end{array}$ \\
\hline $\begin{array}{l}\text { Erythromycin } \\
\text { Moxifloxacin }\end{array}$ & 500 & 5 & 6 & 7 & 8 & 9 & 10 & $\begin{array}{c}330,978 \\
573.3 \\
\end{array}$ & $\begin{array}{c}{[134,164]} \\
{[167]}\end{array}$ \\
\hline Rifaximin & 8000 & 9 & 10 & 11 & 12 & 13 & 14 & 7961 & [168] \\
\hline
\end{tabular}

$\mathrm{NR}=$ Not a relevant concentration for this antimicrobial agent. 


\section{Conclusions}

So what does all of this mean for existing and new CDI treatments? The preferred characteristics of the ideal CDI therapeutic are easy to state: Potent bactericidal activity against all $C$. difficile ribotypes, low potential for mutational resistance, narrow spectrum activity that results in minimal gut microflora disruption, a good pharmacokinetic profile that yields high enough luminal concentrations sufficient to inhibit/kill $C$. difficile that leads to washout of residual toxins and spores (although biofilm retention of toxins/spores may complicate this aim), and finally no recurrence of CDI after excretion of antibiotic. The efficacy of the antimicrobial against $C$. difficile and the indigenous gut microflora, and likelihood of recurrence can be assessed using in vitro models and to a lesser extent in animal models of CDI, but human trials are where the most pivotal data are generated.

One aspect not evaluated extensively in this review is the effect of the antimicrobial agent on the physiology of $C$. difficile and the normal gut microflora at the levels of gene transcription and translation. Antimicrobial agents have been studied for their effects against $C$. difficile at sub-MIC in several studies at the transcriptional and also the whole organism levels [169-172] and been shown to affect the toxin production and expression of colonisation structures of $C$. difficile. These studies demonstrate interesting observations but based on the faecal concentrations presented in Table 4 should be interpreted with caution as they rely on vegetative $C$. difficile being exposed to sub-MIC which may not be the case in all CDI patients. Novel antimicrobial agents, both CDI therapeutics and agents for other infections, would ideally not stimulate $C$. difficile to express virulence determinants or elevate their levels of expression. However, such considerations are not necessarily criteria for discounting the development of an agent and these types of studies are not often performed in drug development programmes. In terms of preventing CDI, it is imperative that resistance development in C. difficile is limited as this provides C. difficile with a competitive advantage as it may facilitate CDI earlier in the course of a therapeutic antimicrobial. Reduced susceptibility to metronidazole may potentially result in therapeutic failure due to low bioactive drug concentrations in the colon and could predispose to greater likelihood of recurrent CDI, although clinical data supporting this hypothesis are lacking. Conversely, reduced susceptibility to fidaxomicin and vancomycin is unlikely to affect primary treatment efficacy for CDI due to very high luminal concentrations in the gut. Antimicrobial agents are integral in the aetiology of CDI and although resistance is not a prerequisite for CDI to occur, there is now substantial evidence that mutation to a resistant phenotype may confer a significant selective advantage within the gut ecosystem. Limiting the spread of antimicrobial resistance in $C$. difficile should be a primary goal for clinicians and scientists, and prospective monitoring of resistance phenotypes and genotypes are essential in achieving this.

\section{Author Contributions}

S.D.B and M.H.W contributed equally to the writing of the paper.

\section{Conflicts of Interest}

S.D.B has received funding from Procarta Biosystems and travel grants from Bayer and Targanta Therapeutics. M.H.W has received consulting fees from Abbott Laboratories, Actelion, Astellas, Astra-Zeneca, Bayer, Cerexa, Cubist, Durata, The European Tissue Symposium, The Medicines 
Company, MedImmune, Merck, Motif Biosciences, Nabriva, Optimer, Paratek, Pfizer, Roche, Sanofi-Pasteur, Seres, Summit, and Synthetic Biologics, and lecture fees from Abbott, Alere, Astellas, Astra-Zeneca and Pfizer; grant support from Abbott, Actelion, Astellas, bioMerieux, Cubist, Da Volterra, The European Tissue Symposium, Merck and Summit.

\section{References}

1. Bartlett, J.G.; Moon, N.; Chang, T.W.; Taylor, N.; Onderdonk, A.B. Role of Clostridium difficile in antibiotic-associated pseudomembranous colitis. Gastroenterology 1978, 75, 778-782.

2. George, R.H.; Symonds, J.M.; Dimock, F.; Brown, J.D.; Arabi, Y.; Shinagawa, N.; Keighley, M.R.; Alexander-Williams, J.; Burdon, D.W. Identification of Clostridium difficile as a cause of pseudomembranous colitis. Br. Med. J. 1978, 1, 695 .

3. Owens, R.C., Jr.; Donskey, C.J.; Gaynes, R.P.; Loo, V.G.; Muto, C.A. Antimicrobial-associated risk factors for Clostridium difficile infection. Clin. Infect. Dis. 2008, 46, S19-S31.

4. O’Brien, J.A.; Lahue, B.J.; Caro, J.J.; Davidson, D.M. The emerging infectious challenge of Clostridium difficile-associated disease in Massachusetts hospitals: Clinical and economic consequences. Infect. Control Hosp. Epidemiol. 2007, 28, 1219-1227.

5. Kyne, L.; Hamel, M.B.; Polavaram, R.; Kelly, C.P. Health care costs and mortality associated with nosocomial diarrhea due to Clostridium difficile. Clin. Infect. Dis. 2002, 34, 346-353.

6. He, M.; Miyajima, F.; Roberts, P.; Ellison, L.; Pickard, D.J.; Martin, M.J.; Connor, T.R.; Harris, S.R.; Fairley, D.; Bamford, K.B.; et al. Emergence and global spread of epidemic healthcare-associated Clostridium difficile. Nat. Genet. 2013, 45, 109-113.

7. Tedesco, F.J.; Barton, R.W.; Alpers, D.H. Clindamycin-associated colitis. A prospective study. Ann. Intern. Med. 1974, 81, 429-433.

8. Fawley, W.N.; Parnell, P.; Verity, P.; Freeman, J.; Wilcox, M.H. Molecular epidemiology of endemic Clostridium difficile infection and the significance of subtypes of the United Kingdom epidemic strain (PCR ribotype 1). J. Clin. Microbiol. 2005, 43, 2685-2696.

9. Freeman, J.; Vernon, J.; Morris, K.; Nicholson, S.; Todhunter, S.; Longshaw, C.; Wilcox, M.H. Pan-European longitudinal surveillance of antibiotic resistance among prevalent Clostridium difficile ribotypes. Clin. Microbiol. Infect. 2015, 21, doi:10.1016/j.cmi.2014.09.017.

10. Reil, M.; Hensgens, M.P.; Kuijper, E.J.; Jakobiak, T.; Gruber, H.; Kist, M.; Borgmann, S. Seasonality of Clostridium difficile infections in Southern Germany. Epidemiol. Infect. 2012, 140, 1787-1793.

11. Terhes, G.; Maruyama, A.; Latkoczy, K.; Szikra, L.; Konkoly-Thege, M.; Princz, G.; Nagy, E.; Urban, E. In vitro antibiotic susceptibility profile of Clostridium difficile excluding PCR ribotype 027 outbreak strain in Hungary. Anaerobe 2014, 30C, 41-44.

12. Spigaglia, P.; Barbanti, F.; Mastrantonio, P. Multidrug resistance in European Clostridium difficile clinical isolates. J. Antimicrob. Chemother. 2011, 66, 2227-2234.

13. Lachowicz, D.; Pituch, H.; Obuch-Woszczatynski, P. Antimicrobial susceptibility patterns of Clostridium difficile strains belonging to different polymerase chain reaction ribotypes isolated in Poland in 2012. Anaerobe 2015, 31, 37-41. 
14. Lee, J.H.; Lee, Y.; Lee, K.; Riley, T.V.; Kim, H. The changes of PCR ribotype and antimicrobial resistance of Clostridium difficile in a tertiary care hospital over 10 years. J. Med. Microbiol. 2014, 63, 819-823.

15. Huang, H.; Fang, H.; Weintraub, A.; Nord, C.E. Distinct ribotypes and rates of antimicrobial drug resistance in Clostridium difficile from Shanghai and Stockholm. Clin. Microbiol. Infect. 2009, 15, 1170-1173.

16. Usui, M.; Nanbu, Y.; Oka, K.; Takahashi, M.; Inamatsu, T.; Asai, T.; Kamiya, S.; Tamura, Y. Genetic relatedness between Japanese and European isolates of Clostridium difficile originating from piglets and their risk associated with human health. Front. Microbiol. 2014, 5, e513.

17. Pelaez, T.; Alcala, L.; Blanco, J.L.; Alvarez-Perez, S.; Marin, M.; Martin-Lopez, A.; Catalan, P.; Reigadas, E.; Garcia, M.E.; Bouza, E. Characterization of swine isolates of Clostridium difficile in Spain: A potential source of epidemic multidrug resistant strains? Anaerobe 2013, 22, 45-49.

18. Pirs, T.; Avbersek, J.; Zdovc, I.; Krt, B.; Andlovic, A.; Lejko-Zupanc, T.; Rupnik, M.; Ocepek, M. Antimicrobial susceptibility of animal and human isolates of Clostridium difficile by broth microdilution. J. Med. Microbiol. 2013, 62, 1478-1485.

19. Spigaglia, P.; Mastrantonio, P. Comparative analysis of Clostridium difficile clinical isolates belonging to different genetic lineages and time periods. J. Med. Microbiol. 2004, 53, 1129-1136.

20. Spigaglia, P.; Drigo, I.; Barbanti, F.; Mastrantonio, P.; Bano, L.; Bacchin, C.; Puiatti, C.; Tonon, E.; Berto, G.; Agnoletti, F. Antibiotic resistance patterns and PCR-ribotyping of Clostridium difficile strains isolated from swine and dogs in Italy. Anaerobe 2015, 31, 42-46.

21. Solomon, K.; Fanning, S.; McDermott, S.; Murray, S.; Scott, L.; Martin, A.; Skally, M.; Burns, K.; Kuijper, E.; Fitzpatrick, F.; et al. PCR ribotype prevalence and molecular basis of macrolide-lincosamide-streptogramin B (MLSB) and fluoroquinolone resistance in Irish clinical Clostridium difficile isolates. J. Antimicrob. Chemother. 2011, 66, 1976-1982.

22. Tenover, F.C.; Tickler, I.A.; Persing, D.H. Antimicrobial-resistant strains of Clostridium difficile from North America. Antimicrob. Agents Chemother. 2012, 56, 2929-2932.

23. Goudarzi, M.; Goudarzi, H.; Alebouyeh, M.; Azimi Rad, M.; Shayegan Mehr, F.S.; Zali, M.R.; Aslani, M.M. Antimicrobial susceptibility of Clostridium difficile clinical isolates in Iran. Iran. Red Crescent Med. J. 2013, 15, 704-711.

24. Kuijper, E.J.; Barbut, F.; Brazier, J.S.; Kleinkauf, N.; Eckmanns, T.; Lambert, M.L.; Drudy, D.; Fitzpatrick, F.; Wiuff, C.; Brown, D.J.; et al. Update of Clostridium difficile infection due to PCR ribotype 027 in Europe, 2008. Euro Surveill. 2008, 13, 1-7.

25. Bacci, S.; St-Martin, G.; Olesen, B.; Bruun, B.; Olsen, K.E.; Nielsen, E.M.; Molbak, K. Outbreak of Clostridium difficile 027 in North Zealand, Denmark, 2008-2009. Euro Surveill. 2009, 14, 1-3.

26. Johnson, S.; Samore, M.H.; Farrow, K.A.; Killgore, G.E.; Tenover, F.C.; Lyras, D.; Rood, J.I.; DeGirolami, P.; Baltch, A.L.; Rafferty, M.E.; et al. Epidemics of diarrhea caused by a clindamycin-resistant strain of Clostridium difficile in four hospitals. N. Engl. J. Med. 1999, 341, 1645-1651.

27. Farrow, K.A.; Lyras, D.; Rood, J.I. Genomic analysis of the erythromycin resistance element Tn5398 from Clostridium difficile. Microbiology 2001, 147, 2717-2128. 
28. Spigaglia, P.; Carucci, V.; Barbanti, F.; Mastrantonio, P. ErmB determinants and Tn916-Like elements in clinical isolates of Clostridium difficile. Antimicrob. Agents Chemother. 2005, 49, 2550-2553.

29. Tang-Feldman, Y.J.; Henderson, J.P.; Ackermann, G.; Feldman, S.S.; Bedley, M.; Silva, J., Jr.; Cohen, S.H. Prevalence of the ermB gene in Clostridium difficile strains isolated at a university teaching hospital from 1987 through 1998. Clin. Infect. Dis. 2005, 40, 1537-1540.

30. Spigaglia, P.; Barbanti, F.; Dionisi, A.M.; Mastrantonio, P. Clostridium difficile isolates resistant to fluoroquinolones in Italy: Emergence of PCR ribotype 018. J. Clin. Microbiol. 2010, 48, 2892-2896.

31. Schmidt, C.; Loffler, B.; Ackermann, G. Antimicrobial phenotypes and molecular basis in clinical strains of Clostridium difficile. Diagn. Microbiol. Infect. Dis. 2007, 59, 1-5.

32. Lebel, S.; Bouttier, S.; Lambert, T. The cme gene of Clostridium difficile confers multidrug resistance in Enterococcus faecalis. FEMS Microbiol. Lett. 2004, 238, 93-100.

33. Keessen, E.C.; Hensgens, M.P.; Spigaglia, P.; Barbanti, F.; Sanders, I.M.; Kuijper, E.J.; Lipman, L.J. Antimicrobial susceptibility profiles of human and piglet Clostridium difficile PCR-ribotype 078. Antimicrob. Resist. Infect. Control 2013, 2, doi:10.1186/2047-2994-2-14.

34. Ilchmann, C.; Zaiss, N.H.; Speicher, A.; Christner, M.; Ackermann, G.; Rohde, H. Comparison of resistance against erythromycin and moxifloxacin, presence of binary toxin gene and PCR ribotypes in Clostridium difficile isolates from 1990 and 2008. Eur. J. Clin. Microbiol. Infect. Dis. 2010, 29, 1571-1573.

35. Wasels, F.; Spigaglia, P.; Barbanti, F.; Mastrantonio, P. Clostridium difficile erm(B)-containing elements and the burden on the in vitro fitness. J. Med. Microbiol. 2013, 62, 1461-1467.

36. Chopra, I.; Roberts, M. Tetracycline antibiotics: Mode of action, applications, molecular biology, and epidemiology of bacterial resistance. Microbiol. Mol. Biol. Rev. 2001, 65, 232-260.

37. Smith, C.J.; Markowitz, S.M.; Macrina, F.L. Transferable tetracycline resistance in Clostridium difficile. Antimicrob. Agents Chemother. 1981, 19, 997-1003.

38. Wust, J.; Hardegger, U. Transferable resistance to clindamycin, erythromycin, and tetracycline in Clostridium difficile. Antimicrob. Agents Chemother. 1983, 23, 784-786.

39. Jasni, A.S.; Mullany, P.; Hussain, H.; Roberts, A.P. Demonstration of conjugative transposon (Tn5397)-mediated horizontal gene transfer between Clostridium difficile and Enterococcus faecalis. Antimicrob. Agents Chemother. 2010, 54, 4924-4926.

40. Barbut, F.; Mastrantonio, P.; Delmee, M.; Brazier, J.; Kuijper, E.; Poxton, I. Prospective study of Clostridium difficile infections in Europe with phenotypic and genotypic characterisation of the isolates. Clin. Microbiol. Infect. 2007, 13, 1048-1057.

41. Noren, T.; Alriksson, I.; Akerlund, T.; Burman, L.G.; Unemo, M. In vitro susceptibility to 17 antimicrobials of clinical Clostridium difficile isolates collected in 1993-2007 in Sweden. Clin. Microbiol. Infect. 2010, 16, 1104-1110.

42. Huang, H.; Weintraub, A.; Fang, H.; Nord, C.E. Antimicrobial resistance in Clostridium difficile. Int. J. Antimicrob. Agents 2009, 34, 516-522.

43. Spigaglia, P.; Barbanti, F.; Mastrantonio, P. Tetracycline resistance gene tet(W) in the pathogenic bacterium Clostridium difficile. Antimicrob. Agents Chemother. 2008, 52, 770-773. 
44. Mullany, P.; Wilks, M.; Lamb, I.; Clayton, C.; Wren, B.; Tabaqchali, S. Genetic analysis of a tetracycline resistance element from Clostridium difficile and its conjugal transfer to and from Bacillus subtilis. J. Gen. Microbiol. 1990, 136, 1343-1349.

45. Dong, D.; Zhang, L.; Chen, X.; Jiang, C.; Yu, B.; Wang, X.; Peng, Y. Antimicrobial susceptibility and resistance mechanisms of clinical Clostridium difficile from a Chinese tertiary hospital. Int. J. Antimicrob. Agents 2013, 41, 80-84.

46. Hachler, H.; Berger-Bachi, B.; Kayser, F.H. Genetic characterization of a Clostridium difficile erythromycin-clindamycin resistance determinant that is transferable to Staphylococcus aureus. Antimicrob. Agents Chemother. 1987, 31, 1039-1045.

47. Corver, J.; Bakker, D.; Brouwer, M.S.; Harmanus, C.; Hensgens, M.P.; Roberts, A.P.; Lipman, L.J.; Kuijper, E.J.; van Leeuwen, H.C. Analysis of a Clostridium difficile PCR ribotype 078100 kilobase island reveals the presence of a novel transposon, Tn6164. BMC Microbiol. 2012, 12, e130.

48. Knetsch, C.; Connor, T.; Mutreja, A.; van Dorp, S.; Sanders, I.; Browne, H.; Harris, D.; Lipman, L.; Keessen, E.; Corver, J.; et al. Whole genome sequencing reveals potential spread of Clostridium difficile between humans and farm animals in the Netherlands, 2002 to 2011. Euro Surveill. 2014, 19, 1-12.

49. Bakker, D.; Corver, J.; Harmanus, C.; Goorhuis, A.; Keessen, E.C.; Fawley, W.N.; Wilcox, M.H.; Kuijper, E.J. Relatedness of human and animal Clostridium difficile PCR ribotype 078 isolates determined on the basis of multilocus variable-number tandem-repeat analysis and tetracycline resistance. J. Clin. Microbiol. 2010, 48, 3744-3749.

50. Aksoy, D.Y.; Unal, S. New antimicrobial agents for the treatment of Gram-positive bacterial infections. Clin. Microbiol. Infect. 2008, 14, 411-420.

51. Stevens, D.L.; Ma, Y.; Salmi, D.B.; McIndoo, E.; Wallace, R.J.; Bryant, A.E. Impact of antibiotics on expression of virulence-associated exotoxin genes in methicillin-sensitive and methicillin-resistant Staphylococcus aureus. J. Infect. Dis. 2007, 195, 202-211.

52. Gemmell, C.G.; Ford, C.W. Virulence factor expression by Gram-positive cocci exposed to subinhibitory concentrations of linezolid. J. Antimicrob. Chemother. 2002, 50, 665-672.

53. Baines, S.D.; Noel, A.R.; Huscroft, G.S.; Todhunter, S.L.; O’Connor, R.; Hobbs, J.K.; Freeman, J.; Lovering, A.M.; Wilcox, M.H. Evaluation of linezolid for the treatment of Clostridium difficile infection caused by epidemic strains using an in vitro human gut model. J. Antimicrob. Chemother. 2011, 66, 1537-1546.

54. Pelaez, T.; Alonso, R.; Perez, C.; Alcala, L.; Cuevas, O.; Bouza, E. In vitro activity of linezolid against Clostridium difficile. Antimicrob. Agents Chemother. 2002, 46, 1617-1618.

55. Citron, D.M.; Merriam, C.V.; Tyrrell, K.L.; Warren, Y.A.; Fernandez, H.; Goldstein, E.J. In vitro activities of ramoplanin, teicoplanin, vancomycin, linezolid, bacitracin, and four other antimicrobials against intestinal anaerobic bacteria. Antimicrob. Agents Chemother. 2003, 47, 2334-2338.

56. Marin, M.; Martin, A.; Alcala, L.; Cercenado, E.; Iglesias, C.; Reigadas, E.; Bouza, E. Clostridium difficile isolates with high linezolid MICs harbor the multiresistance gene cfr. Antimicrob. Agents Chemother. 2015, 59, 586-589.

57. Rashid, M.U.; Dalhoff, A.; Weintraub, A.; Nord, C.E. In vitro activity of MCB3681 against Clostridium difficile strains. Anaerobe 2014, 28, 216-219. 
58. Andersson, M.I.; MacGowan, A.P. Development of the quinolones. J. Antimicrob. Chemother. 2003, 51, 1-11.

59. Drudy, D.; Quinn, T.; O’Mahony, R.; Kyne, L.; O’Gaora, P.; Fanning, S. High-level resistance to moxifloxacin and gatifloxacin associated with a novel mutation in gyrB in toxin-A-negative, toxin-B-positive Clostridium difficile. J. Antimicrob. Chemother. 2006, 58, 1264-1267.

60. Dridi, L.; Tankovic, J.; Burghoffer, B.; Barbut, F.; Petit, J.C. gyrA and gyrB mutations are implicated in cross-resistance to Ciprofloxacin and moxifloxacin in Clostridium difficile. Antimicrob. Agents Chemother. 2002, 46, 3418-3421.

61. Ackermann, G.; Tang, Y.J.; Kueper, R.; Heisig, P.; Rodloff, A.C.; Silva, J., Jr.; Cohen, S.H. Resistance to moxifloxacin in toxigenic Clostridium difficile isolates is associated with mutations in gyrA. Antimicrob. Agents Chemother. 2001, 45, 2348-2353.

62. Saxton, K.; Baines, S.D.; Freeman, J.; O’Connor, R.; Wilcox, M.H. Effects of exposure of Clostridium difficile PCR ribotypes 027 and 001 to fluoroquinolones in a human gut model. Antimicrob. Agents Chemother. 2009, 53, 412-420.

63. Dridi, L.; Tankovic, J.; Petit, J.C. CdeA of Clostridium difficile, a new multidrug efflux transporter of the MATE family. Microb. Drug Resist. 2004, 10, 191-196.

64. Spigaglia, P.; Barbanti, F.; Mastrantonio, P.; Brazier, J.S.; Barbut, F.; Delmee, M.; Kuijper, E.; Poxton, I.R. Fluoroquinolone resistance in Clostridium difficile isolates from a prospective study of C. difficile infections in Europe. J. Med. Microbiol. 2008, 57, 784-789.

65. Walkty, A.; Boyd, D.A.; Gravel, D.; Hutchinson, J.; McGeer, A.; Moore, D.; Simor, A.; Suh, K.; Taylor, G.; Miller, M.; Mulvey, M.R. Molecular characterization of moxifloxacin resistance from Canadian Clostridium difficile clinical isolates. Diagn. Microbiol. Infect. Dis. 2010, 66, 419-424.

66. Drudy, D.; Kyne, L.; O’Mahony, R.; Fanning, S. gyrA Mutations in fluoroquinolone-resistant Clostridium difficile PCR-027. Emerg. Infect. Dis. 2007, 13, 504-505.

67. Kuwata, Y.; Tanimoto, S.; Sawabe, E.; Shima, M.; Takahashi, Y.; Ushizawa, H.; Fujie, T.; Koike, R.; Tojo, N.; Kubota, T.; et al. Molecular epidemiology and antimicrobial susceptibility of Clostridium difficile isolated from a university teaching hospital in Japan. Eur. J. Clin. Microbiol. Infect. Dis. 2015, 34, 763-772.

68. Mena, A.; Riera, E.; López-Causapé, C.; Weber, I.; Pérez, J.L.; Oliver, A. In vivo selection of moxifloxacin-resistant Clostridium difficile. Antimicrob. Agents Chemother. 2012, 56, 2788-2789.

69. Linder, J.A.; Huang, E.S.; Steinman, M.A.; Gonzales, R.; Stafford, R.S. Fluoroquinolone prescribing in the United States: 1995 to 2002. Am. J. Med. 2005, 118, 259-268.

70. Garey, K.W.; Salazar, M.; Shah, D.; Rodrigue, R.; DuPont, H.L. Rifamycin antibiotics for treatment of Clostridium difficile-associated diarrhea. Ann. Pharmacother. 2008, 42, 827-835.

71. O’Connor, J.R.; Galang, M.A.; Sambol, S.P.; Hecht, D.W.; Vedantam, G.; Gerding, D.N.; Johnson, S. Rifampin and rifaximin resistance in clinical isolates of Clostridium difficile. Antimicrob. Agents Chemother. 2008, 52, 2813-2817.

72. Curry, S.R.; Marsh, J.W.; Shutt, K.A.; Muto, C.A.; O’Leary, M.M.; Saul, M.I.; Pasculle, A.W.; Harrison, L.H. High frequency of rifampin resistance identified in an epidemic Clostridium difficile clone from a large teaching hospital. Clin. Infect. Dis. 2009, 48, 425-429. 
73. Campbell, E.A.; Korzheva, N.; Mustaev, A.; Murakami, K.; Nair, S.; Goldfarb, A.; Darst, S.A. Structural Mechanism for Rifampicin Inhibition of Bacterial RNA Polymerase. Cell 2001, 104, 901-912.

74. Johnson, S.; Schriever, C.; Galang, M.; Kelly, C.P.; Gerding, D.N. Interruption of recurrent Clostridium difficile-associated diarrhea episodes by serial therapy with vancomycin and rifaximin. Clin. Infect. Dis. 2007, 44, 846-848.

75. Johnson, S.; Schriever, C.; Patel, U.; Patel, T.; Hecht, D.W.; Gerding, D.N. Rifaximin Redux: Treatment of recurrent Clostridium difficile infections with rifaximin immediately post-vancomycin treatment. Anaerobe 2009, 15, 290-291.

76. Carman, R.J.; Boone, J.H.; Grover, H.; Wickham, K.N.; Chen, L. In vivo selection of rifamycin resistant Clostridium difficile during rifaximin therapy. Antimicrob. Agents Chemother. 2012, 56, 6019-6020.

77. Debast, S.B.; Bauer, M.P.; Kuijper, E.J. European Society of Clinical Microbiology and Infectious Diseases: Update of the treatment guidance document for Clostridium difficile infection. Clin. Microbiol. Infect. 2014, 20, 1-26.

78. Venugopal, A.A.; Johnson, S. Fidaxomicin: A novel macrocyclic antibiotic approved for treatment of Clostridium difficile infection. Clin. Infect. Dis. 2012, 54, 568-574.

79. Babakhani, F.; Seddon, J.; Sears, P. Comparative microbiological studies of transcription inhibitors fidaxomicin and the rifamycins in Clostridium difficile. Antimicrob. Agents Chemother. 2014, 58, 2934-2937.

80. Finegold, S.M.; Molitoris, D.; Vaisanen, M.L.; Song, Y.; Liu, C.; Bolanos, M. In vitro activities of OPT-80 and comparator drugs against intestinal bacteria. Antimicrob. Agents Chemother. 2004, 48, 4898-4902.

81. Leeds, J.A.; Sachdeva, M.; Mullin, S.; Barnes, S.W.; Ruzin, A. In vitro selection, via serial passage, of Clostridium difficile mutants with reduced susceptibility to fidaxomicin or vancomycin. J. Antimicrob. Chemother. 2014, 69, 41-44.

82. Goldstein, E.J.; Citron, D.M.; Sears, P.; Babakhani, F.; Sambol, S.P.; Gerding, D.N. Comparative susceptibilities to fidaxomicin (OPT-80) of isolates collected at baseline, recurrence, and failure from patients in two phase III trials of fidaxomicin against Clostridium difficile infection. Antimicrob. Agents Chemother. 2011, 55, 5194-5199.

83. Kaihovaara, P.; Hook-Nikanne, J.; Uusi-Oukari, M.; Kosunen, T.U.; Salaspuro, M. Flavodoxindependent pyruvate oxidation, acetate production and metronidazole reduction by Helicobacter pylori. J. Antimicrob. Chemother. 1998, 41, 171-177.

84. Musher, D.M.; Aslam, S.; Logan, N.; Nallacheru, S.; Bhaila, I.; Borchert, F.; Hamill, R.J. Relatively poor outcome after treatment of Clostridium difficile colitis with metronidazole. Clinical infectious diseases 2005, 40, 1586-1590.

85. Pepin, J.; Alary, M.E.; Valiquette, L.; Raiche, E.; Ruel, J.; Fulop, K.; Godin, D.; Bourassa, C. Increasing risk of relapse after treatment of Clostridium difficile colitis in Quebec, Canada. Clin. Infect. Dis. 2005, 40, 1591-1597.

86. Baines, S.D.; O’Connor, R.; Freeman, J.; Fawley, W.N.; Harmanus, C.; Mastrantonio, P.; Kuijper, E.J.; Wilcox, M.H. Emergence of reduced susceptibility to metronidazole in Clostridium difficile. J. Antimicrob. Chemother. 2008, 62, 1046-1052. 
87. Pelaez, T.; Alcala, L.; Alonso, R.; Rodriguez-Creixems, M.; Garcia-Lechuz, J.M.; Bouza, E. Reassessment of Clostridium difficile susceptibility to metronidazole and vancomycin. Antimicrob. Agents Chemother. 2002, 46, 1647-1650.

88. Brazier, J.S.; Fawley, W.; Freeman, J.; Wilcox, M.H. Reduced susceptibility of Clostridium difficile to metronidazole. J. Antimicrob. Chemother. 2001, 48, 741-742.

89. Jang, S.S.; Hansen, L.M.; Breher, J.E.; Riley, D.A.; Magdesian, K.G.; Madigan, J.E.; Tang, Y.J.; Silva, J., Jr.; Hirsh, D.C. Antimicrobial susceptibilities of equine isolates of Clostridium difficile and molecular characterization of metronidazole-resistant strains. Clin. Infect. Dis. 1997, 25, S266-S267.

90. Barbut, F.; Decre, D.; Burghoffer, B.; Lesage, D.; Delisle, F.; Lalande, V.; Delmee, M.; Avesani, V.; Sano, N.; Coudert, C.; Petit, J.C. Antimicrobial susceptibilities and serogroups of clinical strains of Clostridium difficile isolated in France in 1991 and 1997. Antimicrob. Agents Chemother. 1999, 43, 2607-2611.

91. Pelaez, T.; Cercenado, E.; Alcala, L.; Marin, M.; Martin-Lopez, A.; Martinez-Alarcon, J.; Catalan, P.; Sanchez-Somolinos, M.; Bouza, E. Metronidazole resistance in Clostridium difficile is heterogeneous. J. Clin. Microbiol. 2008, 46, 3028-3032.

92. Moura, I.; Spigaglia, P.; Barbanti, F.; Mastrantonio, P. Analysis of metronidazole susceptibility in different Clostridium difficile PCR ribotypes. J. Antimicrob. Chemother. 2012, 68, 362-365.

93. Purdell, J.; Fawley, W.N.; Freeman, J.; Wilcox, M.H. Investigation of outcome in cases of Clostridium difficile infection due to isolates with reduced susceptibility to metronidazole. In Proceedings of the 21st European Congress of Clinical Microbiology and Infectious Diseases, Milan, Italy, 7-10 May 2011; Abstract O499.

94. Gal, M.; Brazier, J.S. Metronidazole resistance in Bacteroides spp. carrying nim genes and the selection of slow-growing metronidazole-resistant mutants. J. Antimicrob. Chemother. 2004, 54, $109-116$.

95. Husain, F.; Veeranagouda, Y.; Hsi, J.; Meggersee, R.; Abratt, V.; Wexler, H.M. Two multidrug-resistant clinical isolates of Bacteroides fragilis carry a novel metronidazole resistance nim gene (nimJ). Antimicrob. Agents Chemother. 2013, 57, 3767-3774.

96. Carlier, J.P.; Sellier, N.; Rager, M.N.; Reysset, G. Metabolism of a 5-nitroimidazole in susceptible and resistant isogenic strains of Bacteroides fragilis. Antimicrob. Agents Chemother. 1997, 41, 1495-1499.

97. Chong, P.M.; Lynch, T.; McCorrister, S.; Kibsey, P.; Miller, M.; Gravel, D.; Westmacott, G.R.; Mulvey, M.R. Proteomic analysis of a NAP1 Clostridium difficile clinical isolate resistant to metronidazole. PLoS ONE 2014, 9, e82622.

98. Lynch, T.; Chong, P.; Zhang, J.; Hizon, R.; Du, T.; Graham, M.R.; Beniac, D.R.; Booth, T.F.; Kibsey, P.; Miller, M.; et al. Characterization of a stable, metronidazole-resistant Clostridium difficile clinical isolate. PLoS ONE 2013, 8, e53757.

99. Moura, I.; Monot, M.; Tani, C.; Spigaglia, P.; Barbanti, F.; Norais, N.; Dupuy, B.; Bouza, E.; Mastrantonio, P. Multidisciplinary analysis of a nontoxigenic Clostridium difficile strain with stable resistance to metronidazole. Antimicrob. Agents Chemother. 2014, 58, 4957-4960. 
100. Ammam, F.; Meziane-Cherif, D.; Mengin-Lecreulx, D.; Blanot, D.; Patin, D.; Boneca, I.G.; Courvalin, P.; Lambert, T.; Candela, T. The functional van $G_{C d}$ cluster of Clostridium difficile does not confer vancomycin resistance. Mol. Microbiol. 2013, 89, 612-625.

101. Ammam, F.; Marvaud, J.C.; Lambert, T. Distribution of the vanG-like gene cluster in Clostridium difficile clinical isolates. Can. J. Microbiol. 2012, 58, 547-551.

102. Sebaihia, M.; Wren, B.W.; Mullany, P.; Fairweather, N.F.; Minton, N.; Stabler, R.; Thomson, N.R.; Roberts, A.P.; Cerdeno-Tarraga, A.M.; Wang, H.; et al. The multidrug-resistant human pathogen Clostridium difficile has a highly mobile, mosaic genome. Nat. Genet. 2006, 38, 779-786.

103. Settle, C.D.; Wilcox, M.H.; Fawley, W.N.; Corrado, O.J.; Hawkey, P.M. Prospective study of the risk of Clostridium difficile diarrhoea in elderly patients following treatment with cefotaxime or piperacillin-tazobactam. Aliment. Pharmacol. Ther. 1998, 12, 1217-1223.

104. Wilcox, M.H.; Freeman, J.; Fawley, W.; MacKinlay, S.; Brown, A.; Donaldson, K.; Corrado, O. Long-term surveillance of cefotaxime and piperacillin-tazobactam prescribing and incidence of Clostridium difficile diarrhoea. J. Antimicrob. Chemother. 2004, 54, 168-172.

105. Borriello, S.P.; Barclay, F.E. An in vitro model of colonisation resistance to Clostridium difficile infection. J. Med. Microbiol. 1986, 21, 299-309.

106. Larson, H.E.; Borriello, S.P. Quantitative study of antibiotic-induced susceptibility to Clostridium difficile enterocecitis in hamsters. Antimicrob. Agents Chemother. 1990, 34, 1348-1353.

107. Freeman, J.; Baines, S.D.; Jabes, D.; Wilcox, M.H. Comparison of the efficacy of ramoplanin and vancomycin in both in vitro and in vivo models of clindamycin-induced Clostridium difficile infection. J. Antimicrob. Chemother. 2005, 56, 717-725.

108. Baines, S.D.; Freeman, J.; Wilcox, M.H. Effects of piperacillin/tazobactam on Clostridium difficile growth and toxin production in a human gut model. J. Antimicrob. Chemother. 2005, 55, 974-982.

109. Baines, S.D.; Saxton, K.; Freeman, J.; Wilcox, M.H. Tigecycline does not induce proliferation or cytotoxin production by epidemic Clostridium difficile strains in a human gut model. J. Antimicrob. Chemother. 2006, 58, 1062-1065.

110. Freeman, J.; Baines, S.D.; Saxton, K.; Wilcox, M.H. Effect of metronidazole on growth and toxin production by epidemic Clostridium difficile PCR ribotypes 001 and 027 in a human gut model. J. Antimicrob. Chemother. 2007, 60, 83-91.

111. Baines, S.D.; O’Connor, R.; Saxton, K.; Freeman, J.; Wilcox, M.H. Comparison of oritavancin versus vancomycin as treatments for clindamycin-induced Clostridium difficile PCR ribotype 027 infection in a human gut model. J. Antimicrob. Chemother. 2008, 62, 1078-1085.

112. Baines, S.D.; Freeman, J.; Wilcox, M.H. Tolevamer is not efficacious in the neutralization of cytotoxin in a human gut model of Clostridium difficile infection. Antimicrob. Agents Chemother. 2009, 53, 2202-2204.

113. Baines, S.D.; O’Connor, R.; Huscroft, G.; Saxton, K.; Freeman, J.; Wilcox, M.H. Mecillinam: A low-risk antimicrobial agent for induction of Clostridium difficile infection in an in vitro human gut model. J. Antimicrob. Chemother. 2009, 63, 838-839.

114. Baines, S.D.; O’Connor, R.; Saxton, K.; Freeman, J.; Wilcox, M.H. Activity of vancomycin against epidemic Clostridium difficile strains in a human gut model. J. Antimicrob. Chemother. 2009, 63, $520-525$. 
115. Baines, S.D.; Crowther, G.S.; Todhunter, S.L.; Freeman, J.; Chilton, C.H.; Fawley, W.N.; Wilcox, M.H. Mixed infection by Clostridium difficile in an in vitro model of the human gut. J. Antimicrob. Chemother. 2013, 68, 1139-1143.

116. Crowther, G.S.; Baines, S.D.; Todhunter, S.L.; Freeman, J.; Chilton, C.H.; Wilcox, M.H. Evaluation of NVB302 versus vancomycin activity in an in vitro human gut model of Clostridium difficile infection. J. Antimicrob. Chemother. 2013, 68, 168-176.

117. Baines, S.D.; Crowther, G.S.; Freeman, J.; Todhunter, S.; Vickers, R.; Wilcox, M.H. SMT19969 as a treatment for Clostridium difficile infection: An assessment of antimicrobial activity using conventional susceptibility testing and an in vitro gut model. J. Antimicrob. Chemother. 2014, 70, $182-189$.

118. Chilton, C.H.; Crowther, G.S.; Baines, S.D.; Todhunter, S.L.; Freeman, J.; Locher, H.H.; Athanasiou, A.; Wilcox, M.H. In vitro activity of cadazolid against clinically relevant Clostridium difficile isolates and in an in vitro gut model of C. difficile infection. J. Antimicrob. Chemother. 2014, 69, 697-705.

119. Pultz, N.J.; Donskey, C.J. Effect of antibiotic treatment on growth of and toxin production by Clostridium difficile in the cecal contents of mice. Antimicrob. Agents Chemother. 2005, 49, 3529-3532.

120. Adams, D.A.; Riggs, M.M.; Donskey, C.J. Effect of fluoroquinolone treatment on growth of and toxin production by epidemic and nonepidemic Clostridium difficile strains in the cecal contents of mice. Antimicrob. Agents Chemother. 2007, 51, 2674-2678.

121. Nerandzic, M.M.; Donskey, C.J. Effect of ceftobiprole treatment on growth of and toxin production by Clostridium difficile in cecal contents of mice. Antimicrob. Agents Chemother. 2011, 55, 2174-2177.

122. Jump, R.L.; Li, Y.; Pultz, M.J.; Kypriotakis, G.; Donskey, C.J. Tigecycline exhibits inhibitory activity against Clostridium difficile in the colon of mice and does not promote growth or toxin production. Antimicrob. Agents Chemother. 2011, 55, 546-549.

123. Abujamel, T.; Cadnum, J.L.; Jury, L.A.; Sunkesula, V.C.; Kundrapu, S.; Jump, R.L.; Stintzi, A.C.; Donskey, C.J. Defining the vulnerable period for re-establishment of Clostridium difficile colonization after treatment of $C$. difficile infection with oral vancomycin or metronidazole. PLOS ONE 2013, 8, e76269.

124. Naaber, P.; Mikelsaar, R.H.; Salminen, S.; Mikelsaar, M. Bacterial translocation, intestinal microflora and morphological changes of intestinal mucosa in experimental models of Clostridium difficile infection. J. Med. Microbiol. 1998, 47, 591-598.

125. Bourlioux, $\mathrm{P}$. What is currently known about the molecular mechanisms of colonisation resistance. Anaerobe 1997, 3, 179-184.

126. Larson, H.E.; Welch, A. In vitro and in vivo characterisation of resistance to colonisation with Clostridium difficile. J. Med. Microbiol. 1993, 38, 103-108.

127. Boureau, H.; Decre, D.; Carlier, J.P.; Guichet, C.; Bourlioux, P. Identification of a Clostridium cocleatum strain involved in an anti-Clostridium difficile barrier effect and determination of its mucin-degrading enzymes. Res. Microbiol. 1993, 144, 405-410. 
128. Lawley, T.D.; Clare, S.; Walker, A.W.; Stares, M.D.; Connor, T.R.; Raisen, C.; Goulding, D.; Rad, R.; Schreiber, F.; Brandt, C.; et al. Targeted restoration of the intestinal microbiota with a simple, defined bacteriotherapy resolves relapsing Clostridium difficile disease in mice. PLoS Pathog. 2012, 8, e1002995.

129. van Nood, E.; Speelman, P.; Nieuwdorp, M.; Keller, J. Fecal microbiota transplantation: Facts and controversies. Curr. Opin. Gastroenterol. 2014, 30, 34-39.

130. Kager, L.; Liljeqvist, L.; Malmborg, A.S.; Nord, C.E. Effect of clindamycin prophylaxis on the colonic microflora in patients undergoing colorectal surgery. Antimicrob. Agents Chemother. 1981, 20, 736-740.

131. Brismar, B.; Edlund, C.; Malmborg, A.S.; Nord, C.E. Ciprofloxacin concentrations and impact of the colon microflora in patients undergoing colorectal surgery. Antimicrob. Agents Chemother. 1990, 34, 481-483.

132. Chilton, C.H.; Freeman, J.; Crowther, G.S.; Todhunter, S.L.; Nicholson, S.; Wilcox, M.H. Co-amoxiclav induces proliferation and cytotoxin production of Clostridium difficile ribotype 027 in a human gut model. J. Antimicrob. Chemother. 2012, 67, 951-954.

133. Nord, C.E.; Brismar, B.; Kasholm-Tengve, B.; Tunevall, G. Effect of piperacillin/tazobactam treatment on human bowel microflora. J. Antimicrob. Chemother. 1993, 31, 61-65.

134. Brismar, B.; Edlund, C.; Nord, C.E. Comparative effects of clarithromycin and erythromycin on the normal intestinal microflora. Scand. J. Infect. Dis. 1991, 23, 635-642.

135. Manges, A.R.; Labbe, A.; Loo, V.G.; Atherton, J.K.; Behr, M.A.; Masson, L.; Tellis, P.A.; Brousseau, R. Comparative metagenomic study of alterations to the intestinal microbiota and risk of nosocomial Clostridum difficile-associated disease. J. Infect. Dis. 2010, 202, 1877-1884.

136. Antharam, V.C.; Li, E.C.; Ishmael, A.; Sharma, A.; Mai, V.; Rand, K.H.; Wang, G.P. Intestinal dysbiosis and depletion of butyrogenic bacteria in Clostridium difficile infection and nosocomial diarrhea. J. Clin. Microbiol. 2013, 51, 2884-2892.

137. Moubareck, C.; Gavini, F.; Vaugien, L.; Butel, M.J.; Doucet-Populaire, F. Antimicrobial susceptibility of bifidobacteria. J. Antimicrob. Chemother. 2005, 55, 38-44.

138. Masco, L.; van Hoorde, K.; de Brandt, E.; Swings, J.; Huys, G. Antimicrobial susceptibility of Bifidobacterium strains from humans, animals and probiotic products. J. Antimicrob. Chemother. 2006, 58, 85-94.

139. van Hoek, A.H.; Mayrhofer, S.; Domig, K.J.; Aarts, H.J. Resistance determinant erm(X) is borne by transposon Tn5432 in Bifidobacterium thermophilum and Bifidobacterium animalis subsp. lactis. Int. J. Antimicrob. Agents 2008, 31, 544-548.

140. Wexler, H.M.; Molitoris, E.; Finegold, S.M. In vitro activities of three of the newer quinolones against anaerobic bacteria. Antimicrob. Agents Chemother. 1992, 36, 239-243.

141. Golan, Y.; McDermott, L.A.; Jacobus, N.V.; Goldstein, E.J.; Finegold, S.; Harrell, L.J.; Hecht, D.W.; Jenkins, S.G.; Pierson, C.; Venezia, R.; et al. Emergence of fluoroquinolone resistance among Bacteroides species. J. Antimicrob. Chemother. 2003, 52, 208-213.

142. Stiefel, U.; Nerandzic, M.M.; Pultz, M.J.; Donskey, C.J. Gastrointestinal colonization with a cephalosporinase-producing bacteroides species preserves colonization resistance against vancomycin-resistant enterococcus and Clostridium difficile in cephalosporin-treated mice. Antimicrob. Agents Chemother. 2014, 58, 4535-4542. 
143. Buffie, C.G.; Bucci, V.; Stein, R.R.; McKenney, P.T.; Ling, L.; Gobourne, A.; No, D.; Liu, H.; Kinnebrew, M.; Viale, A.; et al. Precision microbiome reconstitution restores bile acid mediated resistance to Clostridium difficile. Nature 2015, 517, 205-208.

144. Hoverstad, T.; Carlstedt-Duke, B.; Lingaas, E.; Midtvedt, T.; Norin, K.E.; Saxerholt, H.; Steinbakk, M. Influence of ampicillin, clindamycin, and metronidazole on faecal excretion of short-chain fatty acids in healthy subjects. Scand. J. Gastroenterol. 1986, 21, 621-626.

145. Bjorneklett, A.; Midtvedt, T. Influence of three antimicrobial agents-Penicillin, metronidazole, and doxycyclin-On the intestinal microflora of healthy humans. Scand. J. Gastroenterol. 1981, 16, 473-480.

146. Chilton, C.H.; Crowther, G.S.; Freeman, J.; Todhunter, S.L.; Nicholson, S.; Longshaw, C.M.; Wilcox, M.H. Successful treatment of simulated Clostridium difficile infection in a human gut model by fidaxomicin first line and after vancomycin or metronidazole failure. J. Antimicrob. Chemother. 2014, 69, 451-462.

147. Gerding, D.N. Metronidazole for Clostridium difficile-associated disease: Is it okay for Mom? Clin. Infect. Dis. 2005, 40, 1598-1600.

148. Bolton, R.P.; Culshaw, M.A. Faecal metronidazole concentrations during oral and intravenous therapy for antibiotic associated colitis due to Clostridium difficile. Gut 1986, 27, 1169-1172.

149. Arabi, Y.; Dimock, F.; Burdon, D.W.; Alexander-Williams, J.; Keighley, M.R. Influence of neomycin and metronidazole on colonic microflora of volunteers. J. Antimicrob. Chemother. 1979, 5, 531-537.

150. Johnson, S.; Homann, S.R.; Bettin, K.M.; Quick, J.N.; Clabots, C.R.; Peterson, L.R.; Gerding, D.N. Treatment of asymptomatic Clostridium difficile carriers (fecal excretors) with vancomycin or metronidazole. A randomized, placebo-controlled trial. Ann. Intern. Med. 1992, 117, 297-302.

151. Edlund, C.; Barkholt, L.; Olsson-Liljequist, B.; Nord, C.E. Effect of vancomycin on intestinal flora of patients who previously received antimicrobial therapy. Clin. Infect. Dis. 1997, 25, 729-732.

152. Onderdonk, A.B.; Louie, T.J.; Tally, F.P.; Bartlett, J.G. Activity of metronidazole against Escherichia coli in experimental intra-abdominal sepsis. J. Antimicrob. Chemother. 1979, 5, 201-210.

153. Van der Auwera, P.; Pensart, N.; Korten, V.; Murray, B.E.; Leclercq, R. Influence of oral glycopeptides on the fecal flora of human volunteers: Selection of highly glycopeptide-resistant enterococci. J. Infect. Dis. 1996, 173, 1129-1136.

154. Sears, P.; Crook, D.W.; Louie, T.J.; Miller, M.A.; Weiss, K. Fidaxomicin attains high fecal concentrations with minimal plasma concentrations following oral administration in patients with Clostridium difficile infection. Clin. Infect. Dis. 2012, 55, S116-S120.

155. Goldstein, E.J.; Babakhani, F.; Citron, D.M. Antimicrobial activities of fidaxomicin. Clin. Infect. Dis. 2012, 55 S143-S148.

156. Goldstein, E.J.; Citron, D.M.; Tyrrell, K.L.; Merriam, C.V. Comparative in vitro activities of SMT19969, a new antimicrobial agent, against Clostridium difficile and 350 gram-positive and gram-negative aerobic and anaerobic intestinal flora isolates. Antimicrob. Agents Chemother. 2013, 57, 4872-4876. 
157. Tannock, G.W.; Munro, K.; Taylor, C.; Lawley, B.; Young, W.; Byrne, B.; Emery, J.; Louie, T. A new macrocyclic antibiotic, fidaxomicin (OPT-80), causes less alteration to the bowel microbiota of Clostridium difficile-infected patients than does vancomycin. Microbiology 2010, 156, 3354-3359.

158. Chilton, C.H.; Freeman, J.; Baines, S.D.; Crowther, G.S.; Nicholson, S.; Wilcox, M.H. Evaluation of the effect of oritavancin on Clostridium difficile spore germination, outgrowth and recovery. J. Antimicrob. Chemother. 2013, 68, 2078-2082.

159. Liu, F.; Kondo, T.; Toda, Y. Brief physical inactivity prolongs colonic transit time in elderly active men. Int. J. Sports Med. 1993, 14, 465-467.

160. Cummings, J.H.; Bingham, S.A.; Heaton, K.W.; Eastwood, M.A. Fecal weight, colon cancer risk, and dietary intake of non-starch polysaccharides (dietary fiber). Gastroenterology 1993, 103, 1783-1789.

161. Donskey, C. Louis Stokes Cleveland VA Medical Center, Cleveland, OH USA; Personal communication, 2015.

162. Krook, A.; Lindstrom, B.; Kjellander, J.; Jarnerot, G.; Bodin, L. Relation between concentrations of metronidazole and Bacteroides spp. in faeces of patients with Crohn's disease and healthy individuals. J. Clin. Pathol. 1981, 34, 645-650.

163. Brown, R.B.; Martyak, S.N.; Barza, M.; Curtis, L.; Weinstein, L. Penetration of clindamycin phosphate into the abnormal human biliary tract. Ann. Intern. Med. 1976, 84, 168-170.

164. Heimdahl, A.; Kager, L.; Nord, C.E. Changes in the oropharyngeal and colon microflora in relation to antimicrobial concentrations in saliva and faeces. Scand. J. Infect. Dis. 1985, 44, 52-58.

165. Rashid, M.U.; Weintraub, A.; Nord, C.E. Development of antimicrobial resistance in the normal anaerobic microbiota during one year after administration of clindamycin or ciprofloxacin. Anaerobe 2015, 31, 72-77.

166. Brumfitt, W.; Franklin, I.; Grady, D.; Hamilton-Miller, J.M.; Iliffe, A. Changes in the pharmacokinetics of ciprofloxacin and fecal flora during administration of a 7-day course to human volunteers. Antimicrob. Agents Chemother. 1984, 26, 757-761.

167. Burkhardt, O.; Borner, K.; Stass, H.; Beyer, G.; Allewelt, M.; Nord, C.E.; Lode, H. Single- and multiple-dose pharmacokinetics of oral moxifloxacin and clarithromycin, and concentrations in serum, saliva and faeces. Scand. J. Infect. Dis. 2002, 34, 898-903.

168. Jiang, Z.D.; Ke, S.; Palazzini, E.; Riopel, L.; Dupont, H. In vitro activity and fecal concentration of rifaximin after oral administration. Antimicrob. Agents Chemother. 2000, 44, 2205-2206.

169. Drummond, L.J.; Smith, D.G.; Poxton, I.R. Effects of sub-MIC concentrations of antibiotics on growth of and toxin production by Clostridium difficile. J. Med. Microbiol. 2003, 52, 1033-1038.

170. Gerber, M.; Walch, C.; Loffler, B.; Tischendorf, K.; Reischl, U.; Ackermann, G. Effect of sub-MIC concentrations of metronidazole, vancomycin, clindamycin and linezolid on toxin gene transcription and production in Clostridium difficile. J. Med. Microbiol. 2008, 57, 776-783.

171. Emerson, J.E.; Stabler, R.A.; Wren, B.W.; Fairweather, N.F. Microarray analysis of the transcriptional responses of Clostridium difficile to environmental and antibiotic stress. J. Med. Microbiol. 2008, 57, 757-764. 
172. Hennequin, C.; Collignon, A.; Karjalainen, T. Analysis of expression of GroEL (Hsp60) of Clostridium difficile in response to stress. Microb. Pathog. 2001, 31, 255-260.

(C) 2015 by the authors; licensee MDPI, Basel, Switzerland. This article is an open access article distributed under the terms and conditions of the Creative Commons Attribution license (http://creativecommons.org/licenses/by/4.0/). 